OPEN ACCESS

Edited by:

Yan Zhang,

Peking University, China

Reviewed by:

Chen Chen,

Huazhong University of Science and Technology, China

Yahan Liu,

Peking University Health Science

Center, China

*Correspondence:

Teresa Sousa

tsousa@med.up.pt

Specialty section:

This article was submitted to Clinical and Translational Physiology, a section of the journal

Frontiers in Physiology

Received: 23 July 2021 Accepted: 20 September 2021 Published: 11 October 2021

Citation:

Reina-Couto $M$, Pereira-Terra $P$,

Quelhas-Santos J, Silva-Pereira C, Albino-Teixeira A and Sousa T (2021) Inflammation in Human Heart Failure:

Major Mediators and Therapeutic

Targets. Front. Physiol. 12:746494

doi: 10.3389/fphys.2021.746494

\title{
Inflammation in Human Heart Failure: Major Mediators and Therapeutic Targets
}

\begin{abstract}
Marta Reina-Couto 1,2,3, Patrícia Pereira-Terra', Janete Quelhas-Santos ${ }^{1}$, Carolina Silva-Pereira ${ }^{1,2}$, António Albino-Teixeira ${ }^{1,2}$ and Teresa Sousa ${ }^{1,2 *}$
\end{abstract}

\begin{abstract}
1 Departamento de Biomedicina - Unidade de Farmacologia e Terapêutica, Faculdade de Medicina, Universidade do Porto, Porto, Portugal, ${ }^{2}$ Centro de Investigação Farmacológica e Inovação Medicamentosa, Universidade do Porto (MedlnUP),

Porto, Portugal, ${ }^{3}$ Departamento de Medicina Intensiva, Centro Hospitalar e Universitário São João, Porto, Portugal
\end{abstract}

Inflammation has been recognized as a major pathophysiological contributor to the entire spectrum of human heart failure (HF), including HF with reduced ejection fraction, HF with preserved ejection fraction, acute HF and cardiogenic shock. Nevertheless, the results of several trials attempting anti-inflammatory strategies in HF patients have not been consistent or motivating and the clinical implementation of anti-inflammatory treatments for HF still requires larger and longer trials, as well as novel and/or more specific drugs. The present work reviews the different inflammatory mechanisms contributing to each type of HF, the major inflammatory mediators involved, namely tumor necrosis factor alpha, the interleukins 1, 6, 8, 10, 18, and 33, C-reactive protein and the enzymes myeloperoxidase and inducible nitric oxide synthase, and their effects on heart function. Furthermore, several trials targeting these mediators or involving other anti-inflammatory treatments in human HF are also described and analyzed. Future therapeutic advances will likely involve tailored anti-inflammatory treatments according to the patient's inflammatory profile, as well as the development of resolution pharmacology aimed at stimulating resolution of inflammation pathways in HF.

Keywords: inflammation, chronic heart failure (CHF), acute heart failure (AHF), cardiogenic shock (CS), inflammatory mediators, clinical trials, anti-inflammatory strategies

\section{INTRODUCTION}

Heart failure (HF) is a complex clinical syndrome caused by structural and/or functional cardiac abnormalities which result in the impairment of ventricular filling and/or ejection (Ponikowski et al., 2016). Although hemodynamic and neurohormonal counterregulatory responses are activated in order to maintain adequate tissue perfusion, their perpetuation contributes to structural and functional damage at medium and long term (Gullestad et al., 2012; Kemp and Conte, 2012; Braunwald, 2013). Chronic HF (CHF) is currently divided in three categories based on left ventricular ejection fraction (LVEF), namely reduced (HFrEF), preserved (HFpEF) or midrange (HFmrEF) (Ponikowski et al., 2016). This last category (HFmrEF) (Castillo et al., 2020), recently individualized in European guidelines, represents an intermediate range of LVEF that has been less rigorously studied, with clinical characteristics that resemble those of the HFpEF group (Hsu et al., 2017) but with a higher prevalence of coronary artery disease, and so a similar response to the treatment of HFrEF patients (Tomasoni et al., 2019).

Despite therapeutic advances, CHF inexorably progresses with acute episodes, requiring recurrently urgent hospitalization and medical support (Ramani et al., 2010; 
Ponikowski et al., 2016). Although acute heart failure (AHF) frequently refers to this acute decompensation of $\mathrm{CHF}$, it may also correspond to the new-onset form ("de novo HF") caused by direct ischemic, infectious/inflammatory or toxic insults to the myocardium, or indirectly by mechanical development of acute valve insufficiency or cardiac tamponade (Spodick, 2003; Ponikowski et al., 2016). Cardiogenic shock (CS), the severest form of these AHF syndromes, evolve as a continuum from those underlying precipitants until the subsequent state of low cardiac output, organ failure and death (Shpektor, 2010; Mebazaa et al., 2016; van Diepen et al., 2017; Chioncel et al., 2020). Therefore, there is an urgent need to explore new pathophysiological pathways and therapeutic strategies for HF (Yndestad et al., 2006; Heymans et al., 2009; Desai and Stevenson, 2012).

Inflammation is accepted as an important pathophysiological factor in both $\mathrm{AHF}$ and $\mathrm{CHF}$, predicting poor prognosis independently of LVEF (Murphy et al., 2020), although it appears to contribute in different ways to each type of HF (Castillo et al., 2020; Murphy et al., 2020; Srivastava et al., 2020).

In HFpEF, where a more evident association with inflammatory markers is reported, underlying comorbidities, such as obesity, arterial hypertension, diabetes, chronic obstructive pulmonary disease, chronic kidney disease and also aging, trigger a systemic inflammatory state which cause microvascular endothelial cell inflammation associated with increased reactive oxygen species (ROS) production and decreased nitric oxide (NO) bioavailability (Paulus and Tschope, 2013). Chronic inflammation also favors the infiltration of monocytes into the myocardium and further differentiation into proinflammatory macrophages (M1) (Glezeva and Baugh, 2014). These events promote adverse left ventricle remodeling and relaxation impairment (Glezeva and Baugh, 2014).

In HFrEF, myocardial injury is the main trigger for the inflammatory responses mediated by the innate and adaptive immune systems (Van Linthout and Tschope, 2017; Adamo et al., 2020). These are characterized by an initial increase in proinflammatory cytokines and chemokines, along with the infiltration of neutrophils and monocytes into the injured myocardium (Adamo et al., 2020). Subsequently, in the resolution and repair phase (also termed "proliferative"), there is the phagocytosis of apoptotic and necrotic cells, the influx of adaptive immune cells ( $\mathrm{T}$-and B-cells), the activation of collagen-synthesizing myofibroblasts and the production of antiinflammatory and proresolving molecules (e.g., transforming growth factor beta, lipoxins, IL-10) (Adamo et al., 2020). The maturation phase is marked by the apoptosis of reparative cells and scar maturation (Adamo et al., 2020). The maintenance of a chronic inflammatory status may result from sustained myocardial injury and continuous activation of proinflammatory cascades (Reina-Couto et al., 2016; Adamo et al., 2020). Importantly, activation of classic neurohormonal systems, such as the sympathetic nervous system and the renin-angiotensinaldosterone system and hemodynamic overload can also trigger sustained myocardial inflammatory responses - termed as parainflammation - even in the absence of tissue injury (Adamo et al., 2020). The persistence of inflammation may also be caused by a failure in the resolution of inflammation mechanisms
(Reina-Couto et al., 2016). Of note, we and others have observed that $\mathrm{CHF}$ is associated with impaired resolution of inflammation, namely decreased plasma and urinary lipoxins in CHF patients with severe New York Heart Association (NYHA) functional classes compared to CHF patients with mild-to-moderate NYHA classes, and significantly lower plasma concentration of resolvin D1 in patients with CHF compared to healthy age-matched controls (Reina-Couto et al., 2014; Chiurchiu et al., 2019). However, so far, targeting of resolution of inflammation pathways has only been attempted in experimental HF models (Reina-Couto et al., 2016; Kain et al., 2017; Halade et al., 2018).

In $\mathrm{AHF}$, the inflammatory response may arise from antigenic stimulation during infection (e.g., viral myocarditis) or as a result of hemodynamic stress (Chen et al., 2008; Virzi et al., 2018). Systemic congestion and/or peripheral hypoperfusion cause neurohormonal activation, inflammation and oxidative stress which damage endothelial glycocalix and consequently impair endothelial function and fluid homeostasis (Harjola et al., 2017). Inflammatory activation also promotes a prothrombotic and proapoptotic environment (Mentz and O'Connor, 2016). Noteworthy, neurohormonal and inflammatory activation seem to persist beyond the acute event and may contribute to the high rehospitalization rates of this syndrome (Cotter et al., 2008; Reina-Couto et al., 2020). In CS, low cardiac output leads to systemic hypoperfusion caused by or followed by a systemic inflammatory response syndrome and end-organ injury that, if not promptly treated or supported, leads to death (Shpektor, 2010; van Diepen et al., 2017; Chioncel et al., 2020; Cuinet et al., 2020). Very early after CS onset, an inflammatory environment seen in $40 \%$ of the CS patients can contribute to the CS hallmark vasodilation (Kohsaka et al., 2005), with concentrations of various interleukins being associated with mortality (Prondzinsky et al., 2012). This marked inflammatory activation may be due to direct myocardial necrosis and tissue ischemia, inducing the release of damage-associated molecular patterns (DAMPs), mostly recognized by Toll-like receptor 4, highly expressed in the heart, that contributes to myocardial inflammation that occurs in HF (Yang et al., 2016). Also indirect but early secondary hypoperfusion leading to intestinal ischemia may promote the translocation of bacteria and pathogenassociated molecular patterns (PAMPs) (Shpektor, 2010; Cuinet et al., 2020) and, alongside with the release of inflammatory mediators by the spleen or adipose tissue and the parainflammation generated by the comorbidities and endothelial dysfunction, contribute to cardiac deterioration. The intensity of this inflammatory response in CS patients is associated with CS severity (Geppert et al., 2006).

\section{MAJOR INFLAMMATORY MEDIATORS IN HEART FAILURE}

\section{Tumor Necrosis Factor Alpha}

Tumor necrosis factor alpha (TNF- $\alpha)$ is the most studied proinflammatory cytokine in HF (Hanna and Frangogiannis, 2020). In the heart, it can be produced by different types of 
cells such as activated macrophages, cardiomyocytes, vascular cells and mast cells (Urschel and Cicha, 2015; Hanna and Frangogiannis, 2020). TNF- $\alpha$ exists in membrane-bound or cytosolic forms and exerts its actions by binding to cell membrane TNFR1 or TNFR2 receptors (Urschel and Cicha, 2015; Bartekova et al., 2018). TNF- $\alpha$ has been shown to mediate several adverse effects on heart function and structure, namely negative inotropic actions due to the disruption of calcium homeostasis, upregulation of other inflammatory molecules, including induction of inducible NO synthase, enhancement of oxidative stress and consequent mitochondrial DNA damage, promotion of apoptosis and extracellular matrix degradation and increase of microvascular endothelial permeability and activation, enhancing endothelial-leukocyte interactions (Mattila et al., 1992; Yokoyama et al., 1993; Li et al., 2000; Sanders et al., 2001; Sivasubramanian et al., 2001; Suematsu et al., 2003; Haudek et al., 2007; Hamid et al., 2009; Urschel and Cicha, 2015). Increased TNF- $\alpha$ concentrations have been detected in patients with HFrEF, HFpEF, patients with AHF and CS (Levine et al., 1990; Tentolouris et al., 2004; Debrunner et al., 2008; Putko et al., 2014; Pugliese et al., 2020). Despite large evidence of the protective effects of TNF- $\alpha$ inhibition or deletion in experimental models of HF (Berry et al., 2004; Moe et al., 2004; Sun et al., 2007; Jobe et al., 2009), studies in HF patients have been disappointing (Chung et al., 2003; Mann et al., 2004). It has been suggested that TNF- $\alpha$ may exert not only deleterious, but also protective effects, which may be compromised under high intensity TNF- $\alpha$ blockade (Hanna and Frangogiannis, 2020; Murphy et al., 2020). Of note, in experimental cardiac ischemia-reperfusion injury, low doses of TNF- $\alpha$ were shown to be cardioprotective, while higher doses had deleterious cardiac effects (Rathi et al., 2002; Saini et al., 2005). Dose-dependent effects of TNF- $\alpha$ may difficult patient treatment since an optimal amount of this cytokine may be required to counteract excessive remodeling and preserve cardiac function (Hanna and Frangogiannis, 2020).

\section{Interleukin 1}

Interleukin 1 (IL-1) seems to be a major mediator of inflammation in heart diseases (Szekely and Arbel, 2018; Hanna and Frangogiannis, 2020). Among the 11 ligands of the IL-1 family, the best known members acting on the cardiovascular system are IL-1 $\alpha$, IL-1 $\beta$, IL-18, and IL-33 (Hanna and Frangogiannis, 2020). Binding of IL- $1 \alpha$ or IL-1 $\beta$ to the IL-1 type 1 receptor (IL-1R1) initiates inflammatory responses, while the IL-1 receptor type 2 (IL-1R2) functions as a decoy receptor and does not initiate signal transduction. The IL-1 receptor type 3 (IL-1R3) acts as a co-receptor for IL-1R1, being responsible for signaling after the binding of IL- $1 \alpha$ or IL- $1 \beta$ to IL-1R1 (Kaneko et al., 2019). The generation of the active form of IL-1 $\beta$ from its precursor protein is primarily dependent on the enzymatic activity of caspase-1, which in turn is activated by the NOD-like receptor family, pyrin domain containing 3 (NLRP3) inflammasome, a macromolecular structure containing the intracellular sensing protein NLRP3 that responds to dangerassociated signals (Frangogiannis, 2015; Abbate et al., 2020). The activation of the NRLP3 inflammasome in cardiac fibroblasts and cardiomyocytes is induced by myocardial injury and may contribute to the post-infarction inflammatory process that aggravates cardiac injury (Frangogiannis, 2015; Segiet et al., 2019a).

In HF, IL-1 can be produced by immune cells, cardiomyocytes, vascular cells and fibroblasts (Hanna and Frangogiannis, 2020). IL-1 contributes to cardiac dysfunction and remodeling by reducing beta-adrenergic responsiveness of L-type calcium channels and the expression of genes involved in the regulation of calcium homeostasis, by stimulating apoptosis in cardiomyocytes, by inducing the activation of leukocytes and endothelial cells, thus promoting their interaction and increasing the recruitment of inflammatory cells to the myocardium, by favoring fibrosis and by promoting arterial stiffness and microvascular inflammation (Szekely and Arbel, 2018; Hanna and Frangogiannis, 2020). IL-1 $\beta$ also decreases energy production and myocardial contractility by directly damaging mitochondria (Zell et al., 1997; Szekely and Arbel, 2018).

\section{Interleukin 6}

The proinflammatory cytokine interleukin 6 (IL-6) is an important player in the acute phase response of inflammation, being a stimulus for C-reactive protein production by the liver, but also appears to contribute to the transition from acute to chronic inflammation by favoring the change from neutrophil to monocyte recruitment (Gabay, 2006; Huynh et al., 2015; Hanna and Frangogiannis, 2020). IL-6 is produced by several cell types like macrophages, T-lymphocytes, endothelial cells, cardiomyocytes and fibroblasts (Mihara et al., 2012; Hanna and Frangogiannis, 2020). Although both proinflammatory and antiinflammatory effects have been described for this cytokine, its effects in HF appear to be mostly proinflammatory (Bartekova et al., 2018; Hanna and Frangogiannis, 2020).

IL-6 signaling classically involves cytokine binding to the cell surface IL-6 receptor and further association of the cytokinereceptor complex with gp130, dimerization and signaling initiation (Hanna and Frangogiannis, 2020). However, IL-6 receptor can be cleaved by proteases, originating a soluble form that can bind IL-6 and initiate signaling in cells that do not express this receptor, thus increasing the complexity of IL6 cellular effects (Hanna and Frangogiannis, 2020). Regarding the heart, IL-6 has been shown to exert negative inotropic effects and to promote hypertrophy and fibrosis, contributing to increased myocardial stiffness (Hanna and Frangogiannis, 2020). The impairment of myocardial contractility appears to be related with the upregulation of myocardial $\mathrm{NO}$ synthase and downregulation of the sarcoplasmic reticulum $\mathrm{Ca}^{2+}$ ATPase (SERCA2) (Finkel et al., 1992; Villegas et al., 2000). IL-6 has also a negative impact on renal function since it activates the epithelial sodium channel $(\mathrm{ENaC})$ in the distal tubule, impairing natriuresis (Li et al., 2010). Of note, high values of IL-6 are associated with diuretic resistance in HF patients (Kielar et al., 2005; Zhang W. et al., 2012).

Higher IL-6 concentrations have been associated with worse clinical status in CHF patients, being an independent predictor of mortality (Tsutamoto et al., 1998; Maeda et al., 2000). In AHF, IL-6 values at $48-72 \mathrm{~h}$ were found to be independently 
associated with 30-day mortality, but not with 180-day mortality (Perez et al., 2021). CS patients also exhibit an early rise of IL-6 which correlates with the severity of circulatory failure (Cuinet et al., 2020).

\section{Interleukin-8}

Interleukin-8 (IL-8), also termed CXCL8, is a chemokine produced by monocytes, macrophages, neutrophils, epithelial cells, fibroblasts, smooth muscle cells, and endothelial cells, being induced by diverse stimuli such as shear stress, ischemia and hypoxia (Bartekova et al., 2018; Segiet et al., 2019a). It is highly expressed in atherosclerotic lesion macrophages. IL-8 induces the firm adhesion of monocytes in the initial stages of atherogenesis (Apostolakis et al., 2009). In the heart after infarction, it appears to mediate neutrophil activation and chemotaxis, as well as angiogenesis (Apostolakis et al., 2009; Bartekova et al., 2018). IL-8 is increased in CHF, being related with worse outcomes (Damas et al., 2000; Nymo et al., 2014). It also appears to predict HF development after myocardial infarction (Dominguez-Rodriguez et al., 2006; De Gennaro et al., 2012). Increased IL-8 values have also been observed in AHF and CS patients (Prondzinsky et al., 2012; Husebye et al., 2014). An important feature of IL8 is its relative longevity in acute inflammatory conditions, remaining active for a prolonged period, in contrast to other inflammatory cytokines (Apostolakis et al., 2009). It is not clear whether IL-8 contributes to cardiac injury or is cardioprotective in the post-infarcted heart through its angiogenic effects (Bartekova et al., 2018).

\section{Interleukin $\mathbf{1 0}$}

The anti-inflammatory cytokine interleukin 10 (IL-10) is produced by several cell types, such as monocytes, macrophages, activated $\mathrm{T}$ and $\mathrm{B}$ cells, eosinophils, mast cells, dendritic cells, epithelial cells and also tumor cells (Bartekova et al., 2018; Segiet et al., 2019a). It exerts its actions by binding to a specific receptor complex, that consists of two IL-10 receptor-1 (IL-10R1) proteins and two IL-10 receptor-2 (IL10R2) proteins (Bartekova et al., 2018). Major effects of IL-10 include the inhibition of proinflammatory cytokines secretion, reduction of $\mathrm{NO}$ generation and inhibition of ROS production and TNF- $\alpha$-mediated oxidative stress (Kaur et al., 2009). It also appears to counteract TNF- $\alpha$-induced cardiomyocyte apoptosis (Dhingra et al., 2009, 2011). In CHF patients, IL10 values were shown to be either increased when compared to healthy controls and positively correlated with NYHA class, or unchanged (Gullestad et al., 2001b; Dixon et al., 2011). Of note, although $\beta$-adrenergic receptor stimulation has been shown to increase IL-10 production, this anti-inflammatory response appears to be reduced in moderate and severe CHF patients (Ng and Toews, 2016).

Among patients with AHF, IL-10 values did not differ when compared to healthy controls or when patients were stratified according to the presence of renal dysfunction and/or congestion (Pugliese et al., 2020). However, IL-10 values have been shown to be significantly increased and to predict outcomes in CS patients
(Prondzinsky et al., 2012; Reina-Couto et al., 2019b; Cuinet et al., 2020).

\section{Interleukin 18}

The proinflammatory cytokine interleukin 18 (IL-18) is a member of the IL-1 superfamily, being activated similarly to IL$1 \beta$ by caspase- 1 after inflammasome formation (Dinarello et al., 2013; O’Brien et al., 2014; Segiet et al., 2019a). IL-18 exists mostly as a soluble cytokine, although a membrane-bound form can also be found in a subset of macrophages, which can release soluble IL-18 upon stimulation with lipopolysaccharide (O'Brien et al., 2014). The receptor for IL-18 (IL-18R) is a dimer formed by the IL- $18 \mathrm{R} \alpha$ chain, which is the low-affinity binding site for mature IL-18, and the IL-18R $\beta$ chain, which binds the IL-18/IL$18 \mathrm{R} \alpha$ complex, thus forming a high-affinity complex that initiates signaling. These receptor subunits are members of the IL-1R family (Dinarello et al., 2013; O'Brien et al., 2014). Of note, the activation of the IL-18R requires higher amounts of IL-18 (10$20 \mathrm{ng} / \mathrm{mL}$ or higher) than the activation of IL-1R by IL- $1 \alpha$ or IL1 $\beta$ (frequently activated in the $\mathrm{pg} / \mathrm{mL}$ range) (Dinarello et al., 2013). The activity of IL-18 is negatively regulated by IL-18 binding protein (IL-18BP), which is constitutively secreted and binds IL18 with extremely high affinity (Dinarello et al., 2013). Since IL-18BP neutralizes the circulating IL-18, the concentration of the free form of IL-18 is lower than the total circulating IL-18 amount. Moreover, the values of free IL-18 appear to have a better correlation with disease activity than total IL-18 concentration (Dinarello et al., 2013; O’Brien et al., 2014; Kaneko et al., 2019).

In the heart, IL-18 induces an inflammatory response by increasing IFN- $\gamma$ production by infiltrated neutrophils, resident macrophages and endothelial cells and by stimulating IL- $1 \beta$ and TNF- $\alpha$ generation by endothelial cells. IL-18 also increases the expression of vascular cell adhesion molecule 1 (VCAM-1) and intercellular adhesion molecule 1 (ICAM-1) in endothelial cells and cardiomyocytes, thus increasing leukocyte recruitment into the injured myocardium and amplifying cardiac inflammation (Wang et al., 2008). IL-18 has also been shown to induce cardiac hypertrophy and fibrosis, apoptosis, contractile dysfunction and decreased $\beta$-adrenergic receptor responsiveness (Wang et al., 2008; O'Brien et al., 2014; Segiet et al., 2019a). Some of these effects appear to be mediated, at least in part, by the induction of other cytokines and chemokines, such as IL- $1 \beta$, TNF- $\alpha$, and IFN- $\gamma$ (Wang et al., 2008; O’Brien et al., 2014).

The precursor form of IL-18 is constitutively expressed in several cell types such as monocytes, macrophages, epithelial cells, endothelial cells and cardiomyocytes (Dinarello et al., 2013; O’Brien et al., 2014; Segiet et al., 2019a). Following acute MI, the activation of the inflammasome in leukocytes, fibroblasts and cardiomyocytes in the ischemic myocardial tissue increases the local production of IL-18 (O'Brien et al., 2014). In the human failing ischemic myocardium, IL-18 was detected in endothelial cells, macrophages and cardiomyocytes (Mallat et al., 2004; Wang et al., 2008). Both the active and the precursor form of IL18 protein were also shown to be highly expressed in human atherosclerotic plaque macrophages. Furthermore, IL-18 mRNA expression was higher in unstable than in asymptomatic plaques (Mallat et al., 2001). 
Patients with acute MI also have raised systemic IL-18 concentrations which correlate with increased values of atrial natriuretic peptide (ANP), suggesting a role for IL-18 in ANP induction (Seta et al., 2000; O’Brien et al., 2014). Of note, higher IL-18 concentrations are associated with the development of congestive $\mathrm{HF}$ and acute $\mathrm{MI}$ in patients with acute coronary syndromes and with increased mortality in elderly patients with HF (O’Brien et al., 2014; Sanchez et al., 2014).

\section{Interleukin 33}

Interleukin 33 (IL-33) is a member of IL-1 cytokine family and was found to be the ligand for the ST2 receptor which belongs to the IL-1 receptor superfamily (Kunes et al., 2010; Altara et al., 2018; Ghali et al., 2018; Segiet et al., 2019a). The ST2 receptor exists as a functionally active transmembrane form (ST2L) and as a soluble "decoy" receptor form (sST2). sST2 is a mechanically induced cardiomyocyte protein that counteracts the anti-hypertrophic action of IL-33 and other IL-33/ST2Lmediated effects (Kunes et al., 2010; Altara et al., 2018; Ghali et al., 2018; Segiet et al., 2019a). There is considerable evidence that sST2 concentration may be used as an indicator of cardiac stress and remodeling in several cardiovascular diseases such as $\mathrm{HF}$, cardiomyopathies, arterial hypertension and aortic stenosis (Ghali et al., 2018). There have been more studies evaluating sST2 than IL-33 because of its higher concentrations and stability (Altara et al., 2018).

IL-33 is constitutively expressed in endothelial cells of both small and large vessels, but not of brain or glomeruli microvessels. Epithelial cells, smooth muscle cells, fibroblasts and keratinocytes also constitutively express IL-33 (Altara et al., 2018; Segiet et al., 2019a). Adipose tissue and endothelial cells of human atherosclerotic plaque also express IL-33 (Demyanets et al., 2011; Ghali et al., 2018). In the heart, it is predominantly expressed in vascular endothelial cells, but it is also present in fibroblasts and cardiomyocytes, having a fivefold higher expression in fibroblasts than in cardiomyocytes (Kunes et al., 2010; Ghali et al., 2018). Of note, endothelial cells appear to be important to translate myocardial pressure overload into a systemic inflammatory response via IL-33 secretion (Chen et al., 2015). Mechanical strain is the main stimulus for the induction of IL-33 expression in the heart, although proinflammatory cytokines such as TNF- $\alpha$, IL-1 $\beta$, and IFN- $\gamma$ also increase its production (Sanada et al., 2007; Kunes et al., 2010; Demyanets et al., 2013). IL-33 is also released during cell necrosis (Demyanets et al., 2013). Angiotensin II (Ang II) also induces IL-33, with both mediators exerting compensatory effects in response to increased cardiac stretch (Kunes et al., 2010).

In contrast to other members of the IL-1 family such as IL- $1 \alpha$, IL-1 $\beta$ and IL-18, IL-33 has predominantly an antiinflammatory action since it is associated with T-helper type 2 (Th2) immune responses (Kunes et al., 2010). IL-33 exerts cardioprotective effects by reducing cardiomyocyte hypertrophy, cardiomyocyte loss by apoptosis, infarct size, cardiac remodeling and fibrosis (Kunes et al., 2010; Ghali et al., 2018; Segiet et al., 2019a). IL-33 also inhibits the formation of atherosclerotic plaque and reduces angiotensin II-induced ROS and lipid peroxidation products in human cardiomyocytes, an effect that may be attenuated by increased sST2 concentrations
(Kunes et al., 2010; Zhang H.F. et al., 2012). However, IL-33 has also been shown to induce proinflammatory cytokines and adhesion molecules in endothelial cells, promoting vascular permeability and angiogenesis and contributing to the early endothelial dysfunction events involved in the development of atherosclerotic lesions (Choi et al., 2009; Demyanets et al., 2011; Pollheimer et al., 2013).

Some studies have shown that IL-33 concentrations are increased, positively correlated with TNF- $\alpha$ and N-terminalpro-B-type-natriuretic peptide (NT-proBNP) and negatively correlated with LVEF in CHF patients (Zhang H.F. et al., 2012; Xiang et al., 2021). These effects might be due to a reduction of IL-33 bioactivity caused by the increase of sST2 in these patients (Zhang H.F. et al., 2012). Of note, sST2 concentrations are higher in HFrEF than in HFpEF, being a predictor of adverse outcomes in both HF populations (Manzano-Fernandez et al., 2011; Song et al., 2020). In patients with acute worsening of HF, higher sST2 values were also shown to be useful to identify those patients at high-risk of in-hospital death (McCarthy and Januzzi, 2018; Borovac et al., 2020). sST2 concentrations rapidly decreased after hospital admission in AHF patients with uncomplicated shortterm follow-up, while AHF patients that died within 6 months showed a significant increase of sST2 values after admission (Boisot et al., 2008; McCarthy and Januzzi, 2018). Furthermore, higher sST2 concentrations appear to be associated with lower diuretic efficiency in patients with AHF and concomitant renal dysfunction (Espriella et al., 2021).

In contrast to the studies describing an increase of IL-33 in human HF, a recent study showed reduced IL-33 concentrations in HFrEF patients when compared to healthy controls, with patients with HF of ischemic etiology presenting lower values than those with non-ischemic etiology (Segiet et al., 2019b). More studies are needed to clarify whether IL-33 is cardioprotective or contributes to chronic inflammation, aggravating the disease (Altara et al., 2018; Segiet et al., 2019b).

\section{Myeloperoxidase}

Myeloperoxidase (MPO) is a haem-containing enzyme mainly secreted by neutrophils and monocytes, under inflammatory conditions, but has also been detected in other cell types such as macrophages (e.g., infiltrating macrophages in atherosclerotic lesions, peritoneal macrophages), $\mathrm{CD}^{+}$and $\mathrm{CD} 8^{+}$lymphocytes, endothelial cells and platelets (Ndrepepa, 2019; Sousa et al., 2019). MPO activity in macrophages probably results from neutrophils endocytosis or MPO internalization, while in endothelial cells, MPO may be endogenously expressed or originate from external sources (Ndrepepa, 2019). MPO uses $\mathrm{H}_{2} \mathrm{O}_{2}$ derived from leukocyte or vascular NADPH oxidases to produce several oxidizing molecules such as hypochlorous acid $(\mathrm{HClO})$, chloramines, tyrosyl radicals and nitrogen dioxides (Ndrepepa, 2019; Sousa et al., 2019). These MPO-derived ROS and reactive nitrogen species (RNS) exert not only bactericidal effects, but also tissue damaging actions in the cardiovascular and renal systems and in the brain (Ndrepepa, 2019; Sousa et al., 2019; Correa et al., 2020). MPO significantly affects vascular tone, endothelial NO availability, being involved in atherogenesis and cardiovascular disease (Csato et al., 2015; 
Ndrepepa, 2019; Sousa et al., 2019). MPO also contributes to myocardial dysfunction. Experimental studies using MPO knockout mice or an oral MPO inhibitor showed significant less left ventricle dilation and improved left ventricular function in models of myocardial infarction, evidencing a pathophysiological role of MPO in the development of CHF (Askari et al., 2003; Vasilyev et al., 2005; Ali et al., 2016). In humans, CHF patients exhibit higher systemic MPO values, which appear to be associated with worse outcomes (Ng et al., 2006; Tang et al., 2006, 2007). Patients with AHF and CS also show markedly increased circulating MPO values (Reina-Couto et al., 2019b). In acutely decompensated CHF, MPO concentration was also associated with an increased risk for 1-year mortality (Reichlin et al., 2010).

\section{Inducible Nitric Oxide Synthase}

$\mathrm{NO}$ is a free radical involved in several physiological processes relevant for cardiovascular regulation, including vasodilation, regulation of cardiac contractility, modulation of sympathetic outflow, smooth muscle cell proliferation, regulation of renal renin release, natriuresis and immune response (Sousa et al., 2019; Cinelli et al., 2020). It is generated by the oxidation of L-arginine to L-citrulline by NO synthases (NOS), a family of enzymes composed of 2 constitutive isoforms, namely neuronal NOS (nNOS or NOS1) and endothelial NOS (eNOS or NOS3), and one inducible isoform (inducible NO synthase, iNOS or NOS2) (Tang et al., 2014; Sousa et al., 2019; Cinelli et al., 2020). iNOS is not normally produced in most cells, being only expressed after induction or stimulation, generally by proinflammatory cytokines (e.g., TNF- $\alpha$; IL-1 $\beta$; interferon gamma, IFN- $\gamma$ ) and lipopolysaccharide (Cinelli et al., 2020). After induction, iNOS generates high amounts of NO (100- to 1000fold more NO than that produced by eNOS). This production persists for many hours until the enzyme is degraded (Soskic et al., 2011; Cinelli et al., 2020). Although these significant amounts of NO are important for the immune response, they can also contribute to toxic effects and to several human diseases, including HF (Soskic et al., 2011; Cinelli et al., 2020).

iNOS was originally discovered in macrophages but has been shown to be expressed in several cell types, including smooth muscle cells, endothelial cells, cardiomyocytes, hepatocytes, neurons, glial cell and astrocytes (Hemmrich et al., 2003; Cinelli et al., 2020). Regarding cardiac function, high concentrations of NO have been shown to exert negative inotropic and chronotropic effects and to reduce the response to $\beta$-adrenergic stimulation (Cotton et al., 2002). Importantly, under inflammatory conditions, the reaction of NO with ROS is favored, originating RNS such as peroxynitrite (Pacher et al., 2007). Both excess NO and peroxynitrite can cause deleterious effects in the heart, namely cell apoptosis, contractile dysfunction, irreversible reduction of myocardial oxygen consumption and dysregulation of heart rate and rhythm (Cotton et al., 2002; Kaluski et al., 2006; Pacher et al., 2007). The overexpression of iNOS also appears to contribute to myocardial fibrosis and ventricular hypertrophy (Zhang et al., 2007). iNOS has been detected in the hearts of CHF patients (NYHA classes III-IV), regardless of the etiology (Vejlstrup et al., 1998). Furthermore, it was shown to be uniformly distributed in the left and right ventricles and was primarily located in endothelial and vascular smooth muscle cells of the myocardial vasculature of these patients, being also found, although to a lesser extent, in the cardiomyocyte membrane (Vejlstrup et al., 1998). Infiltrating macrophages also account for iNOS expression in the postischemic failing heart (Kingery et al., 2017). Additionally, the activation of iNOS in peripheral vessels of CHF patients (NYHA classes II and III) was shown to be positively associated with systemic BNP concentration and appears to be an independent predictor for worsening HF (Ishibashi et al., 2008). Patients with decompensated CHF were also shown to have increased iNOS expression in peripheral mononuclear cells which was also positively correlated with plasma BNP values (Speranza et al., 2012). As previously mentioned, CS induces a systemic inflammatory response, iNOS activation and excessive production of NO which reduces myocardial contractility, suppresses mitochondrial respiration, attenuates the $\beta$-adrenergic inotropic response and induces inadequate systemic vasodilation, leading to systemic hypoperfusion (Kaluski et al., 2006; Shpektor, 2010). The overproduction of peroxynitrite also aggravates myocardial contractile dysfunction (Kaluski et al., 2006; Pacher et al., 2007).

\section{C-Reactive Protein}

C-reactive protein (CRP) is the best studied acute-phase protein. Its synthesis occurs mainly in the liver, being induced by raised IL- 6 concentrations under conditions of infection, trauma and other inflammatory states (Huynh et al., 2015; Sheriff et al., 2021). In humans, CRP values markedly increase in the first $72 \mathrm{~h}$ after tissue damage, being a sensitive yet non-specific biomarker of inflammation (Huynh et al., 2015; Thiele et al., 2015). CRP is primarily present as a pentamer of five similar polypeptide subunits but can also dissociate into monomers. It is still under debate whether these pentameric and monomeric forms exert different functions. While circulating CRP is pentameric, local deposition of monomeric CRP has been detected in infarcted myocardial tissue, in brain tissue of stroke patients and in the kidney of diabetic patients with severe chronic kidney disease (Thiele et al., 2015; Sheriff et al., 2021).

CRP is a strong chemotaxin/opsonin for macrophages. It binds to phosphorylcholine groups in pathogens and also in nonhealthy human cells (e.g., apoptotic, necrotic, energy-depleted, ischemic/hypoxic cells), marking these cells and consequently inducing their phagocytosis through complement activation (Sheriff et al., 2021). The phagocytosis of ischemic/hypoxic cells in the setting of acute myocardial infarction activates IL6 production, which further induces more CRP, amplifying the immune response. Thus, CRP exacerbates tissue injury and scarring after a cardiovascular event (Griselli et al., 1999; Sheriff et al., 2021). CRP is also present in the myocardium of patients with non-ischemic HF, where it may contribute to myocardial damage through complement system activation and chemotaxis of macrophages (Zimmermann et al., 2009).

CRP can also be produced outside the liver, namely in vascular smooth muscle cells from human coronary arteries, respiratory epithelium, renal cortical tubular cells, neuronal cells, adipocytes and leukocytes (Huynh et al., 2015; Thiele et al., 
2015). Noteworthy, CRP appears to be preferentially expressed in diseased vessels, with its mRNA expression being 7-10-fold higher within atherosclerotic plaque compared to the values found in the liver and normal blood vessels (Yasojima et al., 2001; Calabro et al., 2003; Jabs et al., 2003). CRP seems to promote vascular injury by upregulating endothelial adhesion molecules, monocyte chemoattractant protein-1 (MCP-1), endothelin-1 and endothelial plasminogen activator inhibitor 1 (PAI-1), by contributing to the impairment of endothelial NO bioactivity, by increasing low density lipoprotein (LDL) cholesterol uptake by macrophages and triggering LDL cholesterol oxidation and by inducing complement activation (Ridker and Group, 2003; Bassuk et al., 2004).

CRP is an established independent cardiovascular risk factor, with higher CRP values being associated with major cardiovascular events and mortality and showing prognostic significance for risk stratification (Ridker et al., 2003; Koenig et al., 2006; Jan et al., 2008). Since traditional assays of CRP do not effectively detect basal CRP values, assays for the quantification of high-sensitivity CRP (hsCRP) were developed in order to improve risk stratification, with values below $1 \mathrm{mg} / \mathrm{L}$, from 1 to $3 \mathrm{mg} / \mathrm{L}$ and higher than $3 \mathrm{mg} / \mathrm{L}$ corresponding to low-, moderateand high-risk groups (Bassuk et al., 2004; Huynh et al., 2015).

Increased CRP values appear to be a predictor for $\mathrm{HF}$ development in high-risk populations (Vasan et al., 2003). CRP values higher than $3.23 \mathrm{mg} / \mathrm{L}$ are associated with higher $\mathrm{HF}$ severity evidenced by lower LVEF, higher NYHA functional classes, higher heart rate and increased prevalence of atrial fibrillation (Anand et al., 2005). In AHF, CRP values are increased by fivefold at admission when compared to the concentrations found in CHF patients. Elevated CRP is also related with worse prognosis in ADHF patients and CRP values above $12 \mathrm{mg} / \mathrm{L}$ are associated with increased risk of death and $\mathrm{HF}$ readmissions within 3 months (Michelucci et al., 2007; Lourenco et al., 2010).

The major effects of these inflammatory mediators with relevance for HF pathophysiology are summarized in Figures 1, 2.

\section{ANTI-INFLAMMATORY STRATEGIES IN HUMAN HEART FAILURE}

Several direct or indirect anti-inflammatory therapies have been tested in HF patients. Direct therapies include anti-cytokines therapies, prednisone or colchicine, while indirect strategies repurposed drugs that were previously evidenced to exert pleiotropic anti-inflammatory/immunomodulatory effects.

\section{Anti-cytokine Therapies}

Direct anti-inflammatory therapies have yielded conflicting results. Both anti-TNF- $\alpha$ drugs, namely etanercept (Mann et al., 2004) and infliximab (Chung et al., 2003) are now well accepted to be contraindicated in $\mathrm{HF}$, at least in these high-intensity schemes (Adamo et al., 2020; Murphy et al., 2020). The contradictory results between preclinical, observational, preliminary data and the bigger randomized trial might be due to the abolishment of cardioprotective effect of NF- $\kappa \mathrm{B}$, a downstream effector of
TNF- $\alpha$, as well as to the demonstrated infliximab apoptotic and lytic properties (Hori and Yamaguchi, 2013). On the other hand, anti-IL-1 strategy seems more promising. First, anakinra, an IL-1 receptor antagonist, was shown to improve exercise capacity in both small trials in HFrEF (Van Tassell et al., 2012; Abbate et al., 2013) and HFpEF (Van Tassell et al., 2014) but in longer courses in AHF (Van Tassell et al., 2017) it decreased the composite of death or hospitalization for HF; second, canakinumab, a recombinant human monoclonal antibody that targets IL-1 $\beta$, when added to optimal statin therapy (Ridker et al., 2017), reduced the risk of the composite end point of non-fatal myocardial infarction, non-fatal stroke or cardiovascular death compared with placebo. It showed greater benefit in a dose and hsCRP-dependent fashion, a surrogate biomarker of IL-1 activity, confirming the concept of personalized treatment in HF (Ridker et al., 2018). Nevertheless, although the neutralization of IL-1 $\beta$ or the blockade of IL-1R1 were shown to be protective in human CHF and AHF (Van Tassell et al., 2012; Abbate et al., 2013; Van Tassell et al., 2014, 2016, 2017; Cavalli et al., 2017; Buckley et al., 2018; Everett et al., 2019), circulating IL-1 $\beta$ values are frequently below detection limits, being very difficult to establish a correlation between IL-1 $\beta$ concentration and disease severity (Abbate et al., 2020).

For anti-IL-6 therapy, we still have to wait for major HF trials, with preliminary data in rheumatoid arthritis and in NSTEMI patients showing encouraging results (Kobayashi et al., 2014; Kleveland et al., 2016; Yokoe et al., 2018), as well as for the antiIL-12/-23 therapy where treatment with ustekinumab in patients with psoriasis was associated with improved echocardiographic measures, lower IL-6 and NT-proBNP (Ikonomidis et al., 2017).

Anti-IL-8 treatment has not been evaluated yet in HF patients, although an antibody targeting IL-8 (BMS-986253) is being tested in clinical trials involving patients with malignant tumors or patients with COVID-19 (Bilusic et al., 2019; Dallos, 2020). Of note, since IL-8 expression is redox regulated (Apostolakis et al., 2009), antioxidants may be useful to therapeutically modulate IL- 8 concentrations.

Regarding IL-10 therapy, although its administration was shown to exert cardioprotective effects in animal models (Krishnamurthy et al., 2009; Verma et al., 2012), it has not been tested yet in HF patients.

Therapies targeting IL-18 have been tested in other clinical conditions, but not in HF patients. In patients with type 2 diabetes mellitus or in patients undergoing renal transplantation, trials with a IL-18 neutralizing antibody (GSK1070806) did not show evidence of clinical benefits (McKie et al., 2016; Wlodek et al., 2021). More recently, a clinical trial with a recombinant human IL-18 BP (tadekinig alfa), as well as a short report of a prolonged treatment with this therapy, showed signs of efficacy in patients with a rare systemic autoinflammatory disease (Gabay et al., 2018; Kiltz et al., 2020). With respect to IL-33, it remains to clarify whether it is mainly cardioprotective or contribute to endothelial inflammation, aggravating cardiovascular diseases (Altara et al., 2018; Segiet et al., 2019b). Trials with anti-IL-33 antibodies (etokimab and SAR440340) have been conducted in asthma and atopic dermatitis patients, showing disease improvement with these treatments (Donovan and Hansbro, 2020). Astegolimab, 


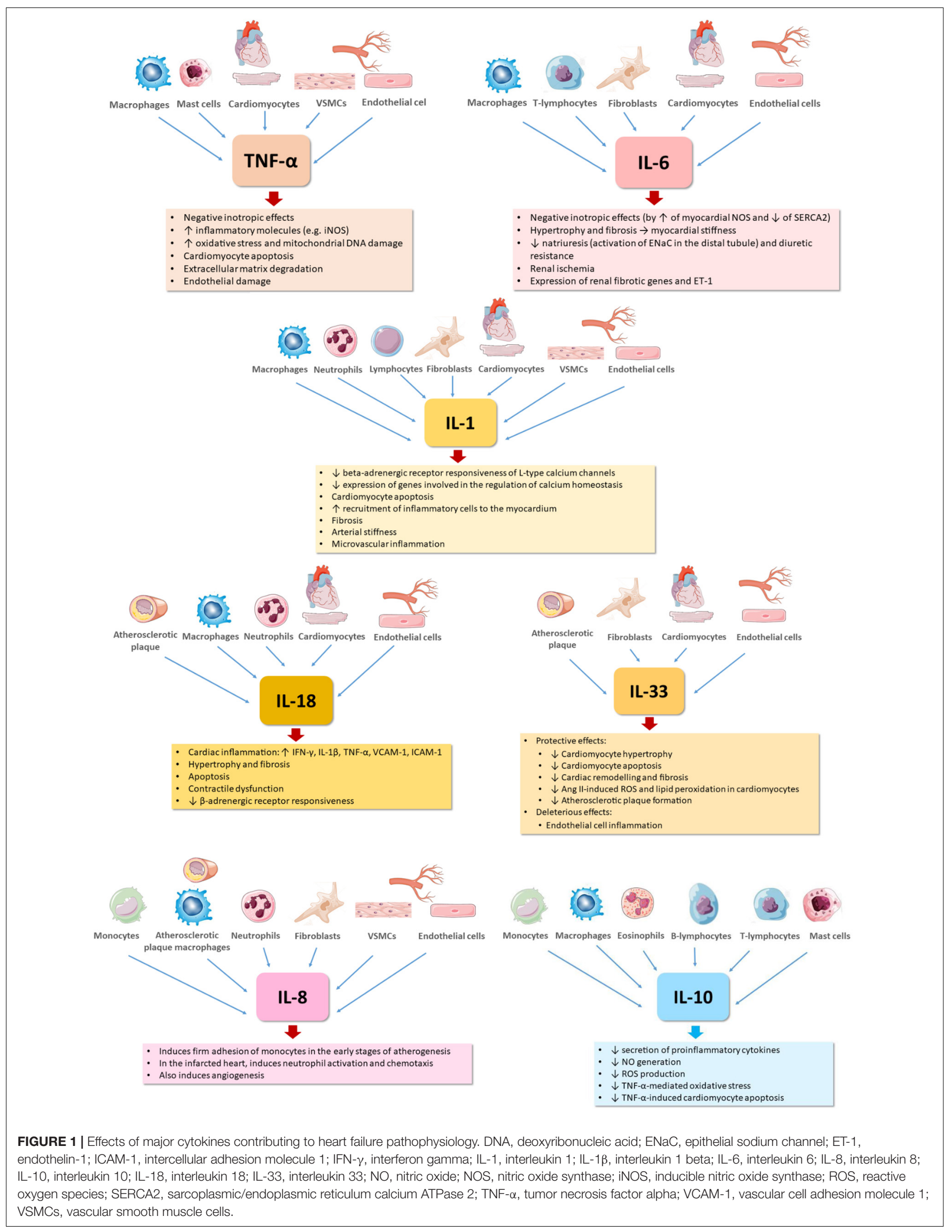




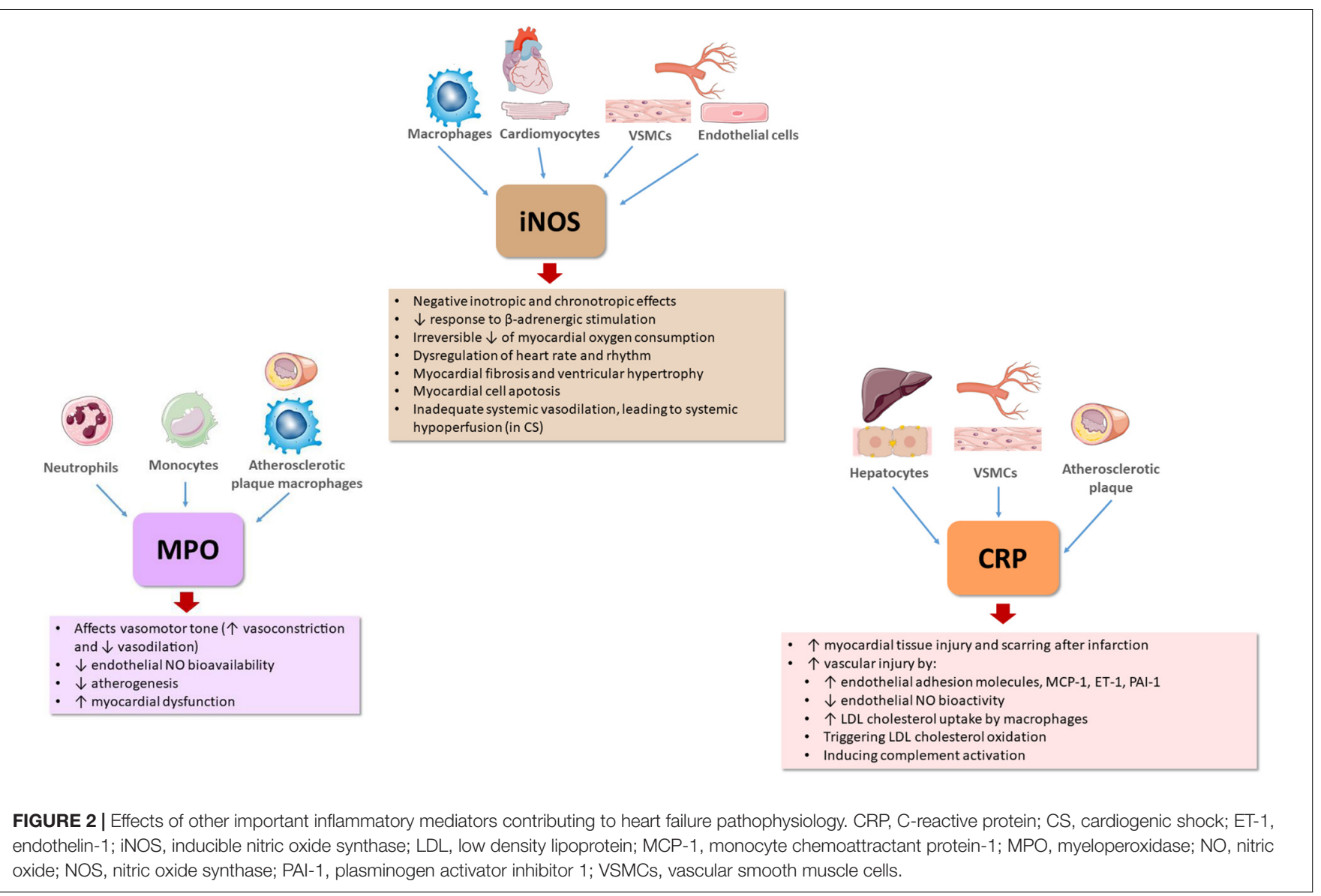

an anti-ST2 antibody that selectively inhibits the IL-33 receptor, was also tested in asthmatics, being able to reduce asthma exacerbation rate (Kelsen et al., 2021). So far, therapies targeting the IL-33/ST2L/sST2 axis have not been tested in human cardiovascular diseases.

\section{Nitric Oxide Synthases Inhibitors}

The role of nitrates and NOS is not unanimous in HF. While in HFrEF, direct donors of NO have its place, at least in patients with optimized treatment or in those not tolerating first line options (Farag et al., 2015) or in ischemic or black patients (Taylor et al., 2004; Real et al., 2018), in AHF, the GALACTIC study failed to demonstrate the improvement in all-cause mortality and rehospitalization with the early intensive and sustained treatment with nitrates (Kozhuharov et al., 2019).

On the contrary, adjunctive use of NOS inhibition in the setting of CS, based on the theory of overproduction of NO by activated iNOS secondary to systemic inflammatory response (Hochman, 2003), was enthusiastic once again in small single-center trials (Cotter et al., 2000, 2003) with L-NMMA (NG-monomethyl L-arginine), a competitive non-specific NOS inhibitor. However, this was not confirmed in the randomized multi-centre trial SHOCK-2 (Dzavík et al., 2007) nor in TRIUMPH trial (TRIUMPH Investigators et al., 2007), which tested another pan-NOS inhibitor (Kaluski et al., 2006). This lack of clinical benefit might have been caused by the inhibition of constitutive NOS isoforms, which contribute to protective effects on vascular tone and microcirculation, promote ventricular relaxation and prevent platelet adhesion and aggregation (Bailey et al., 2007; TRIUMPH Investigators et al., 2007; Shpektor, 2010). Furthermore, the peroxynitrite-mediated effects are not readily reversible by the acute treatment with NOS inhibitors (Cotton et al., 2002). Nevertheless, newer strategies focusing on the specific inhibition of iNOS or on drugs targeting nitrosative stress should also be tested (Shpektor, 2010).

\section{Other Anti-inflammatory Therapies}

The results of indirect anti-inflammatory therapies have as well to be considered. Statins possess pleiotropic properties, namely antioxidant, angiogenic, immunomodulatory, and also anti-inflammatory effects (Costa et al., 2016) evidenced by the reduction of CRP concentrations independently of lipid reduction (Jain and Ridker, 2005). Again, the observational and post hoc analyses data derived from TNT and PROVEIT studies (Scirica et al., 2006; Khush et al., 2007) and the randomized trials UNIVERSE (Krum et al., 2007), CORONA and GISSI-HF showed neutral effects (Kjekshus et al., 2007; Tavazzi et al., 2008b). Nevertheless, the individualized use of these drugs in patients with atherosclerosis and high LDLcholesterol could magnify beneficial effects against detrimental 
inhibition of CoQ10 synthesis that intensifies hypertrophy, especially with high doses of statins in patients with long-term HF (Niazi et al., 2020).

In CHF patients, CRP concentration has also been shown to be reduced by other drugs such as $\beta$-blockers (carvedilol) and angiotensin II receptor antagonists (valsartan), but not by the combination of valsartan with angiotensin converting enzyme inhibitors (Anand et al., 2005; Nessler et al., 2013). In addition, in AHF patients, significantly decreased hsCRP concentrations were observed at 30 days after short-term inotropic support (White et al., 2006). However, the putative effect of hsCRP reduction on mortality could not be demonstrated due to the small sample size (Huynh et al., 2015). In acute settings, CRP values need to be rapidly lowered and this cannot be achieved by using CRP-lowering drugs that take several days to influence CRP concentrations (Pepys et al., 2006; Jones et al., 2012; Szalai et al., 2014). This problem can be solved by CRP apheresis, which removes CRP from the blood plasma after myocardial infarction, significantly reducing the infarct area and improving LVEF (Ries et al., 2018, 2019; Mattecka et al., 2019).

Noteworthy, the GISSI-HF study opened new possibilities as the first large scale clinical trial testing omega- 3 fatty acids, that when adding $1 \mathrm{~g}$ daily to the best medical treatment offered a modest but significant reduction on all-cause mortality and CV hospitalization and proved to be a safe option (Tavazzi et al., 2008a). In a subsequent trial, the reduction seen in inflammatory markers (Moertl et al., 2011), like IL- 6 and TNF- $\alpha$, in the high dose of $4 \mathrm{~g} / \mathrm{d}$ regimen, accompanied by a dosedependent increase of LVEF and improvement of endothelial function, could justify the outcome benefits. Recent trials, like MESA cohort (Block et al., 2019), showed a significant independent inverse correlation between circulating levels of omega-3 fatty acids, specifically eicosapentaenoic acid (EPA), and the occurrence of HF over a long median follow-up period of 13 years, as well as the ability of plasma EPA concentrations to predict the occurrence of $\mathrm{HF}$ in all ethnicities. Also, in the REDUCE-IT trial, very high plasma values of omega3 fatty acids were associated with a reduction of major $\mathrm{CV}$ events (Bhatt et al., 2019) and in the OMEGA REMODEL trial (Heydari et al., 2016), a 6-month treatment with $4 \mathrm{~g}$ daily of omega-3 fatty acids on top of the current guideline-based standard of care was associated with a reduction of adverse left ventricular remodeling, myocardial fibrosis and serum biomarkers of systemic inflammation, namely MPO and ST2. Interestingly, EPA is also the precursor of resolvin E1 (RvE1), one of the specialized proresolving mediators actively contributing to resolution of inflammation. Experimental studies have already shown that RvE1, through its receptor ChemR23, exerts a direct protective effect on cardiomyocytes against ischemia-reperfusion injury and limits infarct size when administered intravenously before reperfusion (Keyes et al., 2010; Reina-Couto et al., 2016; Carracedo et al., 2019). Preliminary studies of our group, conducted in patients with AHF and CS, also demonstrated that RvE1 is increased in AHF and CS and correlated with CRP and MPO (Reina-Couto et al., 2019a).

Despite several lines of evidence indicating an association between increased MPO concentrations and HF pathogenesis and severity, the clinical benefit of MPO inhibition in HF patients remains unknown (Ng et al., 2006; Tang et al., 2006, 2007; Reichlin et al., 2010; Ndrepepa, 2019). A clinical trial is currently evaluating the hemodynamic effects of an oral MPO inhibitor, AZD4831, following baseline, resting and exercise testing in HFpEF patients during right heart catheterization (Gan et al., 2019; Nelander et al., 2021).

Serum uric acid (UA) is widely recognized as a biomarker of oxidative stress in several cardiovascular diseases, including HF (Anker et al., 2003). After cellular damage, increased amounts of available xanthine and hypoxanthine can be converted into UA by xanthine oxidase (XO), upregulated itself in cardiovascular disease. Since XO uses oxygen as an electron acceptor, ROS are also generated, contributing to oxidative stress (Zimmet and Hare, 2006; Sousa et al., 2019). Although several studies and meta-analyses have identified elevations of serum UA as an independent marker of poor prognosis in HF patients (Jankowska et al., 2007; Tamariz et al., 2011) and pre-clinical (Stull et al., 2004) and case-control studies (Gotsman et al., 2012), as well as the later OPT-HF study (Hare et al., 2008), showed that XO inhibition was associated with improved survival in HF, the EXACT-HF trial failed to demonstrate a clinical benefit of high-dose allopurinol in HFrEF patients with increased UA concentrations. This lack of benefit might have resulted from the short duration of this study. The authors also suggested that serum UA might be just a marker of disease severity and prognosis and not a target for therapy, even though there was trend toward lower hospitalizations in the allopurinol group of this study. Other possible explanation is that other metabolic pathways, not targeted by the selective inhibition of $\mathrm{XO}$, may be responsible for the nitroso-redox imbalance, as suggested by the unchanged concentrations of MPO in these patients (Tamariz and Hare, 2015).

\section{Immunomodulators}

Other strategies based not only on classic anti-inflammatory schemes, but in a new concept of modulation of inflammation, as shown by the small trials with intravenous immunoglobulin (IVIg), pentoxifylline and thalidomide or the recent repurposed colchicine, could have a role in HF management. IVIg preparations are known to have anti-infectious, antiinflammatory, and immunomodulatory properties (Nimmerjahn and Ravetch, 2008), but recent prospective, randomized, doubleblind, placebo-controlled trial to evaluate the effect of IVIg on systolic cardiac function in adult patients with idiopathic chronic dilated cardiomyopathy (DCM) and parvovirus cardiac B19V persistence (Hazebroek et al., 2021) did not demonstrate improvement of cardiac systolic function or functional capacity beyond standard medical therapy. Importantly, nor even Gullestad et al. (2001a, 2013) could confirm the IVIg protective effects, years later after their study in 2001, in ischemic patients. This treatment is nowadays reserved as an alternative therapy to myocarditis and inflammatory cardiomyopathy in combination with immunoadsorption (Tschope et al., 2021), which still needs validation in multi-center, double blind studies (Bian et al., 2021). The same author, Gullestad et al. (2005), trying the same rationale of beneficial effects of immunomodulation in HF patients, also tested thalidomide. While immunoregulatory 
TABLE 1 | Trials targeting major inflammatory mediators of HF.

\begin{tabular}{|c|c|c|c|c|c|c|c|}
\hline Target & $\begin{array}{l}\text { Trial acronym/registry } \\
\text { number and Reference }\end{array}$ & Study design & Study population & Intervention & Drug mechanism of action & Follow-up & Outcomes \\
\hline \multirow[t]{4}{*}{ TNF- $\alpha$} & Deswal et al., 1999 & $\begin{array}{l}\text { Randomized } \\
\text { double-blind }\end{array}$ & $\begin{array}{l}18 \mathrm{HFrEF} \text { patients with NYHA } \\
\text { class III (United States) with } \\
\text { LVEF of }<35 \%\end{array}$ & $\begin{array}{l}\text { Intervention groups: single } \\
\text { intravenous infusion of } 1,4 \text {, or } \\
10 \mathrm{mg} / \mathrm{m} 2 \text { of etanercept over } \\
30 \mathrm{~min} \text { ( } n=4 \text { for each dose) } \\
\text { Placebo group }(n=6)\end{array}$ & $\begin{array}{l}\text { TNF- } \alpha \text { inhibitor (dimeric } \\
\text { recombinant protein fusing the } \\
\text { TNF receptor } 2 \text { to the Fc region } \\
\text { of the human IgG1 antibody) }\end{array}$ & 14 days & $\begin{array}{l}\text { - No adverse effects } \\
\text { - } 4 \text { or } 10 \mathrm{mg} / \mathrm{m} 2 \text { of etanercept: } \\
\downarrow \text { TNF- } \alpha, \text { IL } 6 \\
\uparrow \text { quality of life, } 6 \text {-min walk test } \\
\text { distance and ejection fraction }\end{array}$ \\
\hline & Bozkurt et al., 2001 & $\begin{array}{l}\text { Randomized, } \\
\text { double-blind, } \\
\text { placebo-controlled }\end{array}$ & $\begin{array}{l}47 \text { HFrEF patients with NYHA } \\
\text { class III to IV (United States) } \\
\text { with LVEF of }<30 \%\end{array}$ & $\begin{array}{l}\text { Intervention groups: } \\
\text { subcutaneous injections of } \\
\text { etanercept } 5 \mathrm{mg} / \mathrm{m} 2(n=16) \text { or } \\
12 \mathrm{mg} / \mathrm{m} 2(n=15) 2 \times / \text { week for } \\
3 \text { months } \\
\text { Placebo group }(n=16)\end{array}$ & $\begin{array}{l}\text { TNF- } \alpha \text { inhibitor (dimeric } \\
\text { recombinant protein fusing the } \\
\text { TNF receptor } 2 \text { to the Fc region } \\
\text { of the human IgG1 antibody) }\end{array}$ & 3 months & $\begin{array}{l}\text { - Safe treatment; } \\
\text { - Dose-dependent improvement in } \\
\text { LV structure, remodeling and } \\
\text { function }\end{array}$ \\
\hline & Fichtlscherer et al., 2001 & Randomized & $\begin{array}{l}18 \text { patients with CHF } \\
\text { (Germany) with LVEF of } \\
<30 \%\end{array}$ & $\begin{array}{l}\text { Intervention group }(n=13) \text { : single } \\
\text { dose of subcutaneous injection of } \\
25 \text { mg etanercept } \\
\text { Control group }(n=5)\end{array}$ & $\begin{array}{l}\text { TNF- } \alpha \text { inhibitor (dimeric } \\
\text { recombinant protein fusing the } \\
\text { TNF receptor } 2 \text { to the Fc region } \\
\text { of the human IgG1 antibody) }\end{array}$ & 7 days & $\begin{array}{l}\text { - Improved systemic endothelial } \\
\text { vasodilator capacity; } \\
\text { - Positive correlation between the } \\
\text { increase in ACh-induced-forearm } \\
\text { blood flow responses and baseline } \\
\text { TNF- } \alpha \text { serum values }\end{array}$ \\
\hline & $\begin{array}{l}\text { ATTACH (Anti-TNF Therapy } \\
\text { Against Congestive Heart } \\
\text { Failure Trial) } \\
\text { (Chung et al., 2003) }\end{array}$ & $\begin{array}{l}\text { Randomized } \\
\text { double-blind }\end{array}$ & $\begin{array}{l}150 \text { HFrEF patients with } \\
\text { stable NYHA class III or IV } \\
\text { (United States) with LVEF of } \\
\leq 35 \%\end{array}$ & $\begin{array}{l}\text { Intervention groups: } 2 \text {-h } \\
\text { intravenous infusion of infliximab } \\
5 \mathrm{mg} / \mathrm{kg}(n=50) \text {, infliximab } \\
10 \mathrm{mg} / \mathrm{kg}(n=51) \text { at } 0,2 \text { and } \\
6 \text { weeks }\end{array}$ & $\begin{array}{l}\text { TNF- } \alpha \text { inhibitor (Anti-TNF- } \alpha \text {, } \\
\text { mouse-human chimeric } \\
\text { monoclonal antibody) }\end{array}$ & 28 weeks & $\begin{array}{l}\text { - No improvement in clinical status } \\
\text { - } 10 \mathrm{mg} / \mathrm{kg} \text { infliximab: } \uparrow \text { risk of death } \\
\text { or hospitalization } \\
\text { - } 5 \mathrm{mg} / \mathrm{kg} \text { infliximab: } \downarrow \text { CRP, IL-6; } \uparrow \\
\text { EF (modestly) }\end{array}$ \\
\hline
\end{tabular}

\section{RENEWAL (Randomized Randomized} Etanercept Worldwide double-blind,

Evaluation): combined data of placebo-controlled RENAISSANCE and

RECOVER trials in a

pre-specified study

(Mann et al., 2004)

IL-1 D-HART (Diastolic Heart failure Anakinra Response Trial)

NCT01542502

(Van Tassell et al., 2014)

NCT01936844

(Van Tassell et al., 2016)

Randomized,

double blind,

placebo-controlled,

crossover pilot

study

Randomized

double-blinded

placebo-controlled

pilot study

CANTOS (Canakinumab

anti-Inflammatory Thrombosis double-blind trial

Outcome Study)

NCT01327846

(Ridker et al., 2017)
1673 patients with CHF

(United Kingdom, Sweden,

Germany, Holland, Denmark Italy, France, Norway, Israel, Australia, New Zealand,

United States) with LVEF of

$<30 \%$

12 patients with HFpEF (United States)

30 patients with $\mathrm{ADHF}$

(United States) with LVEF of

$<40 \%$

10,061 patients with previous 3 doses of canakinumab

$\mathrm{Ml}$ and hsCRP $\geq 2 \mathrm{mg} / \mathrm{L} \quad(50 \mathrm{mg}, 150 \mathrm{mg}$, and $300 \mathrm{mg}$,

(North America, South administered subcutaneously

America, Europe, Asia, Africa, every 3 months)

Australia)

SC injection of $100 \mathrm{mg}$ of

Says and

or SC injection of placebo daily

11 days or matching placebo
Intervention groups: etanercept TNF- $\alpha$ inhibitor (dimeric

subcutaneous injection $25 \mathrm{mg} 3 x$ recombinant protein fusing the

an additional 14 days of placebo

anakinra for an additional 14 days

$100 \mathrm{mg}$ anakinra twice daily for

3 days followed by once daily for

Inhibits IL-1 binding to the

IL-1 type I receptor

(recombinant, non-glycosylated

form of the endogenous IL-1

receptor antagonist peptide)

LL-1 $\beta$ inhibitor (monoclonal

antibody which binds to human

$\mathrm{L}-1 \beta$, blocking its interaction

with IL-1 receptors) receptor

(recombinant, non-glycosylated

orm of the endogenous $\mathrm{L}-1$

eceptor antagonist peptide)
24 weeks - No effects on the rate of death or hospitalization
48 months $-\downarrow$ rate of recurrent cardiovascular events than placebo, independent of lipid-level lowering - $\uparrow$ incidence of fatal infection than placebo




\begin{tabular}{|c|c|c|c|c|c|c|c|}
\hline Target & $\begin{array}{l}\text { Trial acronym/registry } \\
\text { number and Reference }\end{array}$ & Study design & Study population & Intervention & Drug mechanism of action & Follow-up & Outcomes \\
\hline & $\begin{array}{l}\text { REDHART (Recently } \\
\text { Decompensated Heart Failure } \\
\text { Anakinra Response Trial) } \\
\text { NCT01936909 } \\
\text { (Nan Tassell et al., 2017) }\end{array}$ & $\begin{array}{l}\text { Randomized in one } \\
\text { of } 3 \text { treatment } \\
\text { duration arms }\end{array}$ & $\begin{array}{l}60 \text { patients with recently } \\
\text { decompensated systolic HF } \\
\text { (United States) with LVEF of } \\
<50 \%\end{array}$ & $\begin{array}{l}1: 1: 1 \text { ratio to } 1 \text { daily } \\
\text { subcutaneous injections with } \\
\text { anakinra } 100 \text { mg for } 2 \text { weeks, } \\
12 \text { weeks, or placebo }\end{array}$ & $\begin{array}{l}\text { Inhibits IL-1 binding to the } \\
\text { IL-1 type I receptor } \\
\text { (recombinant, non-glycosylated } \\
\text { form of the endogenous IL-1 } \\
\text { receptor antagonist peptide) }\end{array}$ & 24 weeks & $\begin{array}{l}-\downarrow \text { serum CRP values } \\
-\uparrow \text { peak VO2 in the group } \\
\text { receiving anakinra for } \\
12 \text { weeks. }\end{array}$ \\
\hline & $\begin{array}{l}\text { D-HART2 (Diastolic Heart } \\
\text { Failure Anakinra Response } \\
\text { Trial 2) } \\
\text { NCT02173548 } \\
\text { (Nan Tassell et al., 2018) }\end{array}$ & $\begin{array}{l}\text { 2:1 phase 2, } \\
\text { randomized, } \\
\text { double-blind, } \\
\text { placebo-controlled }\end{array}$ & $\begin{array}{l}31 \text { patients with HFpEF } \\
\text { (Sweden) }\end{array}$ & $\begin{array}{l}\text { IL-1 blockade with anakinra: } \\
100 \text { mg subcutaneously daily } \\
(n=21) \text { or placebo }(n=10) \text { for } \\
12 \text { weeks }\end{array}$ & $\begin{array}{l}\text { Inhibits IL-1 binding to the } \\
\text { IL-1 type I receptor } \\
\text { (recombinant, non-glycosylated } \\
\text { form of the endogenous IL-1 } \\
\text { receptor antagonist peptide) }\end{array}$ & 24 weeks & $\begin{array}{l}-\downarrow \text { serum hsCRP values } \\
\text { - } \downarrow \text { serum NT-pro-BNP }\end{array}$ \\
\hline \multirow[t]{4}{*}{ IL-6 } & Kobayashi et al., 2014 & Pilot study & $\begin{array}{l}20 \text { women with rheumatoid } \\
\text { arthritis (RA) without cardiac } \\
\text { symptoms (Japan) }\end{array}$ & $\begin{array}{l}\text { Tocilizumab (TCZ; } 8 \text { mg/kg IV } \\
\text { every } 4 \text { weeks) prescribed for } \\
\text { patients with RA with an } \\
\text { inadequate clinical response to } \\
\text { methotrexate }\end{array}$ & $\begin{array}{l}\text { IL-6 inhibitor (anti-IL-6 } \\
\text { receptor monoclonal antibody } \\
\text { which binds to soluble and } \\
\text { membrane-bound IL-6 } \\
\text { receptors, inhibiting IL-6 } \\
\text { signaling) }\end{array}$ & 52 weeks & $\begin{array}{l}-\uparrow \text { increased EF } \\
-\downarrow L V M I \text { associated with disease } \\
\text { activity } \\
\text { - regression of LV eccentric } \\
\text { hypertrophy }\end{array}$ \\
\hline & $\begin{array}{l}\text { NCT01491074 } \\
\text { (Kleveland et al., 2016) }\end{array}$ & $\begin{array}{l}\text { Two-center } \\
\text { double-blind, } \\
\text { randomized, } \\
\text { placebo-controlled } \\
\text { phase } 2 \text { trial }\end{array}$ & $\begin{array}{l}117 \text { patients with } \\
\text { non-ST-elevation myocardial } \\
\text { infarction (Norway) }\end{array}$ & $\begin{array}{l}\text { Single dose (intravenous infusion) } \\
\text { of the anti-IL-6R antibody } \\
\text { tocilizumab } 280 \text { mg or matching } \\
\text { placebo }\end{array}$ & $\begin{array}{l}\text { IL-6 inhibitor (anti-IL-6 } \\
\text { receptor monoclonal antibody } \\
\text { which binds to soluble and } \\
\text { membrane-bound IL-6 } \\
\text { receptors, inhibiting IL-6 } \\
\text { signaling) }\end{array}$ & $\begin{array}{l}3 \text { and } \\
6 \text { months }\end{array}$ & $\begin{array}{l}-\downarrow \text { inflammatory response and } \\
\text { primarily PCI-related TnT } \\
\text { release in NSTEMI patients }\end{array}$ \\
\hline & Yokoe et al., 2018 & & $\begin{array}{l}70 \text { patients with RA free of } \\
\text { cardiovascular disease }\end{array}$ & $\begin{array}{l}\text { Tocilizumab prescribed for } \\
\text { patients with active RA - } 8 \mathrm{mg} / \mathrm{kg} \\
\text { of intravenous TCZ every } \\
4 \text { weeks during } 24 \text { weeks }\end{array}$ & $\begin{array}{l}\text { IL-6 inhibitor (anti-IL-6 } \\
\text { receptor monoclonal antibody } \\
\text { which binds to soluble and } \\
\text { membrane-bound IL-6 } \\
\text { receptors, inhibiting IL-6 } \\
\text { signaling) }\end{array}$ & 24 weeks & - $\downarrow$ NT-pro-BNP levels \\
\hline & $\begin{array}{l}\text { RESCUE (Reduction in } \\
\text { Inflammation in Patients With } \\
\text { Advanced Chronic Renal } \\
\text { Disease Utilizing Antibody } \\
\text { Mediated IL-6 Inhibition) } \\
\text { NCT03926117 } \\
\text { (Ridker et al., 2021) }\end{array}$ & $\begin{array}{l}\text { Randomized, } \\
\text { double-blind, } \\
\text { phase } 2 \text { trial (at } 40 \\
\text { clinical sites) }\end{array}$ & $\begin{array}{l}264 \text { participants with } \\
\text { moderate-to-severe CKD and } \\
\text { hsCRP } \geq 2 \mathrm{mg} / \mathrm{L} \text { (high CV } \\
\text { risk) (United States) }\end{array}$ & $\begin{array}{l}66 \text { were randomly assigned to } \\
\text { each of the four treatment groups } \\
(1: 1: 1: 1) \text { to subcutaneous } \\
\text { administration of placebo or } \\
\text { ziltivekimab } 7.5,15 \text {, or } 30 \mathrm{mg} \\
\text { every } 4 \text { weeks }\end{array}$ & $\begin{array}{l}\text { IL-6 inhibitor (monoclonal } \\
\text { antibody directed against the } \\
\text { IL-6 ligand) }\end{array}$ & 24 weeks & $\begin{array}{l}\text { - } \downarrow \text { hsCRP values } \\
\text { - Ziltivekimab was well tolerated }\end{array}$ \\
\hline MPO & $\begin{array}{l}\text { Hemodynamic Effects of a } \\
\text { Novel Myeloperoxidase } \\
\text { Inhibitor With Exercise in } \\
\text { Heart Failure With Preserved } \\
\text { Ejection Fraction - A } \\
\text { Randomized, Double-Blind, } \\
\text { Placebo Controlled Proof of } \\
\text { Principle Study } \\
\text { NCT03611153 }\end{array}$ & $\begin{array}{l}\text { Randomized, } \\
\text { double-blind, } \\
\text { placebo controlled } \\
\text { proof of principle } \\
\text { study }\end{array}$ & $\begin{array}{l}30 \mathrm{HFpEF} \text { patients referred to } \\
\text { the catheterization laboratory } \\
\text { for evaluation of } \\
\text { breathlessness or shortness } \\
\text { of breath }\end{array}$ & $\begin{array}{l}\text { A single administration dose of } \\
30 \mathrm{mg} \text { oral MPO inhibitor } \\
\text { (AZD4831) or placebo given } \\
\text { orally following baseline, resting } \\
\text { and exercise testing in patients } \\
\text { during right heart catheterization. }\end{array}$ & $\begin{array}{l}\text { Potent and selective MPO } \\
\text { inhibitor }\end{array}$ & $\begin{array}{l}\text { 9-14 days } \\
\text { after the } \\
\text { study drug } \\
\text { dosage }\end{array}$ & Ongoing study \\
\hline
\end{tabular}




\begin{tabular}{cl}
\hline Target & $\begin{array}{l}\text { Trial acronym/registry } \\
\text { number and Reference }\end{array}$ \\
\hline CRP & $\begin{array}{l}\text { CORONA (Controlled } \\
\text { Rosuvastatin Multinational } \\
\text { Trial in Heart Failure) } \\
\text { (Kjekshus et al., 2007) }\end{array}$ \\
& \\
& GISSI-HF (Gruppo Italiano \\
& Per Lo Studio Della \\
& Sopravvivenza \\
& Nell'Insufficienza \\
& Cardiaca-Heart Failure) \\
& NCT00336336 \\
& (Tavazzi et al., 2008b) \\
NOS & Cotter et al., 2000
\end{tabular}

\begin{tabular}{lll} 
Study design & Study population & Intervention \\
\hline Single-blind, & 5,011 II-IV NYHA class & Intervention group $(n=2514):$
\end{tabular}

Single-blind,
randomized,
placebo controlled

\section{ischemic}

Intervention group ( $n=2514)$ :

sites in 19 European

countries, Russia, and South Africa) with LVEF

rosuvastatin $10 \mathrm{mg}$ dail

treatment for at least 3 months or placebo $(n=2497)$ with pleiotropic actions (e.g.,
antioxidant, anti-inflammatory,

$$
\text { of }<35 \%
$$

Randomized, 4,574 II-IV NYHA class

double-blind, ischemic and dilated

placebo-controlled cardiomyopathy HFrEF patients (Italy) with mean LVEF of $<45 \%$

Intervention group $(n=2285)$ :

rosuvastatin $10 \mathrm{mg}$ daily

treatment for at least 3 months

or placebo $(n=2289)$ improvement of endothelial function)

HMG-CoA reductase inhibitor with pleiotropic actions (e.g., antioxidant, anti-inflammatory, improvement of endothelia function)

Single-center, preliminary report

LINCS (L-NAME (a NO synthase inhibitor) In the treatment of refractory Cardiogenic Shock) (Cotter et al., 2003)

SHOCK-2 (Should we inhibit nitric Oxide synthase in Cardiogenic Shock 2) (Dzavík et al., 2007)

\section{Multicenter phase} II, randomized, placebo-controlled, dose ranging study

prospective

randomized study complicated with CS (Israel)

L-NMMA - $1 \mathrm{mg} / \mathrm{kg}$ bolus and $1 \mathrm{mg} / \mathrm{kg} / \mathrm{h}$ continuous IV drip for $5 \mathrm{~h}$.

30 patients with refractory CS Intervention group $(n=15)$ : (Israel)

supportive care in addition to

L-NAME - $1 \mathrm{mg} / \mathrm{kg}$ bolus and

$1 \mathrm{mg} / \mathrm{kg} / \mathrm{h}$ continuous IV drip for $5 \mathrm{~h}$;

Control group $(n=15)$ : supportive care alone

79 patients with acute $\mathrm{M}$ complicated by persistent CS (n= 15/15/15/14) ( $n=15 / 15 / 15 / 14)$ $\mathrm{PCl}$ (United States, Canada, Germany, Israel, Austria, Denmark)

\section{L-NMMA}

0.15/0.5/1.0/1.5 mg/kg IV bolus and $0.15 / 0.5 / 1.0 / 1.5 \mathrm{mg} / \mathrm{kg} / \mathrm{h}$ infusion for $5 \mathrm{~h}$;

Placebo group $(n=20): 0.9 \%$ normal saline IV bolus, and $5 \mathrm{~h}$ infusion.

TRIUMPH (Tilarginine
Acetate Injection in a
Randomized International
Study in Unstable MI Patients
With Cardiogenic Shock)
(TRIUMPH Investigators
et al., 2007)

Internationa multicenter, randomized double blind placebo-controlled
398 patients with refractory CS complicating MI despite $\mathrm{PCl}$ (eight countries in North America and Europe)
Intervention group ( $n=206$ ):

\section{Tilarginine (L-NMMA) -}

$1 \mathrm{mg} / \mathrm{kg}$ bolus and $1 \mathrm{mg} / \mathrm{kg} / \mathrm{h}$

infusion for $5 \mathrm{~h}$;

Placebo group $(n=190)$.

\section{Non-selective NOS inhibitor}

Non-selective NOS inhibitor

1-3 months

$$
\begin{array}{ll} 
& -\uparrow B P \\
4 \text { months } & -\uparrow \text { Urinary output } \\
& -\uparrow B P
\end{array}
$$$$
-\uparrow \text { Urinary output }
$$

$\downarrow$ Time of mechanica

ventilation

$\downarrow$ Time of intra aortic ballon pump support

Non-selective NOS inhibitor

$2 \mathrm{~h}$ after $-\mathrm{No}$ adverse effects

study $\quad-\uparrow \mathrm{BP}$ at $15 \mathrm{~min}$ (modestly)

initiation - No effect on BP at $2 \mathrm{~h}$

(MAP - No effects on glucose and

outcome) or urinary output

30 days - No significant differences on

(mortality mortality at 30 days

outcome)

Non-selective NOS inhibitor

6 months

No effect on 30-day all-cause mortality

$-\uparrow$ SBP at $2 h$

No effect on the resolution of shock, on reinfarction, or on renal function.

ACh, acetylcholine; ADHF, acute decompensated heart failure; BP, blood pressure; CHF, chronic heart failure; CKD, chronic kidney disease; CRF, cardiorespiratory fitness; CRP, C-reactive protein; CS, cardiogenic shock; $C V$, cardiovascular; $E F$, ejection fraction; HF, heart failure; HFpEF, Heart failure with preserved ejection fraction; HFrEF, heart failure with reduced ejection fraction; HMG-CoA, $\beta$-hydroxy $\beta$-methylglutaryl Coenzime A; hsCRP, high sensitive C reactive protein; IL-1, interleukin 1; IL-6, interleukin 6; IL-6R, interleukin 6 receptor; L-NAME, N-Nitro-L-Arginine-Methyl Ester; L-NMMA, N-monomethyl L-arginine; LV, left ventricular; LVMI, left ventricular mass index; MI, myocardial infarction; MPO, myeloperoxidase; NOS, nitric oxide synthase; NSTEMI, non-ST segment elevation myocardial infarction; NT-pro-BNP, N-terminal-pro-B-type Natriuretic Peptide; NYHA, New York Heart Association; PCl, percutaneous coronary intervention; RA, rheumatoid arthritis; SBP, systolic blood pressure; SC, subcutaneous; s/CAM-1, soluble intercellular adhesion molecule-1; TCZ, tocilizumab; TNF- $\alpha$, tumor necrosis factor alpha; TnT, troponin $\mathrm{T}_{\text {; }} \mathrm{VO}_{2}$, volume of oxygen consumption 
TABLE 2 | Other anti-inflammatory trials in HF.

\begin{tabular}{|c|c|c|c|c|c|c|}
\hline $\begin{array}{l}\text { Trial acronym/registry } \\
\text { number and Reference }\end{array}$ & Study design & Study population & Intervention & Drug mechanism of action & Follow-up & Outcomes \\
\hline Gullestad et al., 2001a & $\begin{array}{l}\text { Randomized, } \\
\text { double-blind, } \\
\text { placebo-controlled } \\
\text { study }\end{array}$ & $\begin{array}{l}40 \text { II-III NYHA class } \\
\text { ischemic and dilated } \\
\text { cardiomyopathy HFrEF } \\
\text { patients with LVEF of } \\
<40 \% \text { (Norway) }\end{array}$ & $\begin{array}{l}\text { Intravenous immunoglobulin } \\
\text { therapy (IVIG) - induction } \\
\text { therapy ( } 1 \text { daily infusion at } \\
0.4 \mathrm{~g} / \mathrm{kg} \text { for } 5 \text { days) and } \\
\text { thereafter as monthly infusions } \\
(0.4 \mathrm{~g} / \mathrm{kg} \text { ) for a total of } \\
5 \text { months } \\
\text { or placebo for a total period of } \\
26 \text { weeks ( } 4 \text { weeks after last } \\
\text { IVIG or placebo infusion). }\end{array}$ & $\begin{array}{l}\text { Immunomodulator (influences the } \\
\text { concentration of cytokines and } \\
\text { cytokine modulators; neutralizes } \\
\text { microbial antigens and } \\
\text { autoantibodies; Fc-receptor } \\
\text { blockade; complement inactivation) }\end{array}$ & 6 months & $\begin{array}{l}\text { - } \uparrow \text { anti-inflammatory cytokine } \\
\text { profile (IL-10, IL-1 receptor } \\
\text { antagonist, and soluble tumor } \\
\text { necrosis factor receptors) } \\
\text { - improvement in clinical status } \\
\text { - } \uparrow \text { LVEF } \\
-\downarrow N \text {-terminal pro-atrial } \\
\text { natriuretic peptide }\end{array}$ \\
\hline Sliwa et al., 2002 & $\begin{array}{l}\text { Prospective, } \\
\text { randomized, } \\
\text { double-blind, } \\
\text { placebo-controlled } \\
\text { study }\end{array}$ & $\begin{array}{l}18 \text { IV NYHA class dilated } \\
\text { cardiomyopathy HFrEF } \\
\text { patients (South Africa) with } \\
\text { LVEF of }<25 \%\end{array}$ & $\begin{array}{l}\text { 1-month therapy with } \\
\text { pentoxifylline }(400 \mathrm{mg} 3 \text { times } \\
\text { daily) }(n=9) \text { and placebo }(n=9)\end{array}$ & $\begin{array}{l}\text { Immunomodulator } \\
\text { (phosphodiesterase inhibitor } \\
\text { leading to } \uparrow \text { CAMP and downstream } \\
\text { inhibition of proinflammatory } \\
\text { mediators) }\end{array}$ & 1 month & $\begin{array}{l}-\downarrow \text { TNF- } \alpha \text { levels and } \\
\text { Fas/Apo- } 1 \text { concentrations } \\
\text { - improved symptoms and } \uparrow \\
\text { LVEF }\end{array}$ \\
\hline Sliwa et al., 2004 & $\begin{array}{l}\text { Single-center, } \\
\text { prospective, } \\
\text { double-blind, } \\
\text { randomized, } \\
\text { placebo-controlled }\end{array}$ & $\begin{array}{l}38 \text { II-III NYHA class } \\
\text { ischemic HFrEF patients } \\
\text { (South Africa) with LVEF of } \\
<35 \%\end{array}$ & $\begin{array}{l}2 \text { parallel arms: pentoxifylline } \\
400 \mathrm{mg} \text { TID }(n=20) \text { or a } \\
\text { matching placebo }(n=18) \text { for } \\
6 \text { months in addition to } \\
\text { standard therapy }\end{array}$ & $\begin{array}{l}\text { Immunomodulator } \\
\text { (phosphodiesterase inhibitor } \\
\text { leading to } \uparrow \text { cAMP and downstream } \\
\text { inhibition of proinflammatory } \\
\text { mediators) }\end{array}$ & 6 months & $\begin{array}{l}\text { - } \downarrow \text { in plasma markers of } \\
\text { inflammation, prognosis, and } \\
\text { apoptosis. } \\
\text { - improved symptoms and } \uparrow \\
\text { LVEF }\end{array}$ \\
\hline Gullestad et al., 2005 & $\begin{array}{l}\text { Double-blind, } \\
\text { placebo-controlled } \\
\text { study }\end{array}$ & $\begin{array}{l}56 \text { II-III NYHA class } \\
\text { ischemic and dilated } \\
\text { cardiomyopathy HFrEF } \\
\text { patients (Norway) with LVEF } \\
\text { of }<40 \%\end{array}$ & $\begin{array}{l}\text { Thalidomide ( } 25 \mathrm{mg} \text { QD } \\
\text { increasing to } 200 \mathrm{mg} \mathrm{QD} \text { ) or } \\
\text { placebo and followed up for } \\
12 \text { weeks }\end{array}$ & $\begin{array}{l}\text { Immunomodulator } \\
\text { (alters the concentration of } \\
\text { inflammatory cytokines; } \\
\text { downregulates neutrophils) }\end{array}$ & 3 months & $\begin{array}{l}-\downarrow \text { total neutrophil count and } \\
\uparrow \text { TNF- } \alpha \text { levels } \\
-\downarrow \text { heart rate } \\
-\uparrow \text { in LVEF and improvement } \\
\text { in left ventricular remodeling } \\
\text { with matrix-stabilizing net } \\
\text { effect }\end{array}$ \\
\hline Gong et al., 2006 & $\begin{array}{l}\text { Prospective, } \\
\text { randomized, } \\
\text { placebo-controlled, } \\
\text { single-blind study }\end{array}$ & $\begin{array}{l}71 \text { patients with } \mathrm{CHF} \\
\text { outpatients receiving } \\
\text { conventional treatment } \\
\text { (China) with LVEF of }<35 \%\end{array}$ & $\begin{array}{l}\text { Intervention group }(n=35) \text { : } \\
\text { Methotrexate } 7.5 \text { mg per } \\
\text { week for } 12 \text { weeks } \\
\text { Placebo group }(n=36)\end{array}$ & $\begin{array}{l}\text { Folate analog with } \\
\text { anti-inflammatory properties: } \\
\text { inhibits inflammatory cell } \\
\text { proliferation; } \uparrow \text { extracellular } \\
\text { concentrations of adenosine (which } \\
\text { exerts anti-inflammatory effects by } \\
\text { binding to } \mathrm{A}_{2} \text { receptors) }\end{array}$ & 12 weeks & $\begin{array}{l}-\downarrow \text { TNF- } \alpha, \text { IL-6, MCP-1, } \\
\text { sICAM-1, CRP } \\
-\uparrow \text { IL-10, soluble IL-1 receptor } \\
\text { antagonist } \\
\text { - Improved NYHA functional } \\
\text { class, 6-min walk test } \\
\text { distance and quality of life } \\
\text { scores }\end{array}$ \\
\hline $\begin{array}{l}\text { GISSI-HF (Gruppo Italiano Per } \\
\text { Lo Studio Della Sopravvivenza } \\
\text { Nell'Insufficienza } \\
\text { Cardiaca-Heart Failure) } \\
\text { NCT00336336 } \\
\text { (Tavazzi et al., 2008a) }\end{array}$ & $\begin{array}{l}\text { Randomized, } \\
\text { double-blind, } \\
\text { placebo-controlled }\end{array}$ & $\begin{array}{l}\text { NYHA functional } \\
\text { class II-IV heart failure } \\
\text { irrespective of cause and/or } \\
\text { LVEF (Italy) with mean LVEF } \\
\text { of }<45 \%\end{array}$ & $\begin{array}{l}\text { Intervention: } \mathrm{n}-3 \\
\text { polyunsaturated fatty acids ( } \mathbf{n}-\mathbf{3} \\
\text { PUFA) } 1 \mathrm{~g} \text { daily }(n=3494) \text { vs. } \\
\text { placebo ( } n=3481)\end{array}$ & $\begin{array}{l}\text { Precursors of SPMs (which have } \\
\text { proresolving and anti-inflammatory } \\
\text { effects). } \\
\text { Incorporation of } n \text {-3-PUFA on the } \\
\text { membrane of target cells likely } \\
\text { reduces electrical excitability } \\
\text { (anti-arrhythmic effect). }\end{array}$ & 46.8 months & $\begin{array}{l}-\downarrow \text { in both all-cause mortality } \\
\text { and the composite end point } \\
\text { of all-cause mortality and } \\
\text { hospitalization for } \\
\text { cardiovascular causes } \\
\text { in all the predefined } \\
\text { subgroups, compared with } \\
\text { the placebo group }\end{array}$ \\
\hline
\end{tabular}


TABLE 2 | (Continued)

\begin{tabular}{|c|c|c|c|c|c|c|}
\hline $\begin{array}{l}\text { Trial acronym/registry } \\
\text { number and Reference }\end{array}$ & Study design & Study population & Intervention & Drug mechanism of action & Follow-up & Outcomes \\
\hline $\begin{array}{l}\text { METIS (METhotrexate Therapy } \\
\text { on the Physical Capacity of } \\
\text { Patients With ISchemic Heart } \\
\text { Failure Trial) } \\
\text { (Moreira et al., 2009) }\end{array}$ & $\begin{array}{l}\text { Randomized } \\
\text { double-blind, } \\
\text { placebo-controlled } \\
\text { trial }\end{array}$ & $\begin{array}{l}50 \text { patients with ischemic } \\
\text { CHF (Brazil) with mean } \\
\text { LVEF of }<45 \%\end{array}$ & $\begin{array}{l}\text { Intervention group }(n=25) \text { : } \\
\text { Methotrexate } 7.5 \text { mg per } \\
\text { week plus folic acid } \\
\text { ( } 5 \mathrm{mg} / \text { week) for } 12 \text { weeks } \\
\text { Placebo group ( } n=25) \text { : } \\
\text { Placebo plus folic acid } \\
\text { (5 mg/week), for } 12 \text { weeks }\end{array}$ & $\begin{array}{l}\text { Folate analog with } \\
\text { anti-inflammatory properties: } \\
\text { inhibits inflammatory cell } \\
\text { proliferation; } \uparrow \text { extracellular } \\
\text { concentrations of adenosine (which } \\
\text { exerts anti-inflammatory effects by } \\
\text { binding to } \mathrm{A}_{2} \text { receptors) }\end{array}$ & 12 weeks & $\begin{array}{l}\text { - No effects on CRP } \\
\text { - No effects on 6-min walk test } \\
\text { distance } \\
\text { - Trend toward improved } \\
\text { NYHA scores }\end{array}$ \\
\hline $\begin{array}{l}\text { COPE-ADHF (Cardiac } \\
\text { Outcome Prevention } \\
\text { Effectiveness of } \\
\text { Glucocorticoids in Acute } \\
\text { Decompensated Heart Failure) } \\
\text { (Liu et al., 2014) }\end{array}$ & $\begin{array}{l}\text { Non-blinded } \\
\text { randomized }\end{array}$ & $\begin{array}{l}102 \text { patients with ADHF } \\
\text { (China) with mean LVEF of } \\
<45 \%\end{array}$ & $\begin{array}{l}\text { Intervention group: } \\
\text { dexamethasone }(20 \mathrm{mg} / \mathrm{d}) \text { IV } \\
\text { followed by prednisone (orally, } \\
\text { daily, } 1 \mathrm{mg} / \mathrm{kg} / \mathrm{d} \text { with a } \\
\text { maximum dose of } 60 \mathrm{mg} / \mathrm{d}) \text { for } \\
7 \text { days and then tapered off in } \\
3 \text { days }(n=51) \text {; } \\
\text { Control group }(n=51) \text { : } \\
\text { standard care }\end{array}$ & $\begin{array}{l}\text { Glucocorticoid receptor agonists } \\
\text { that regulate the transcription of } \\
\text { several genes involved in the } \\
\text { inflammatory response. Also } \uparrow \\
\text { the expression of the receptor for } \\
\text { natriuretic peptides (diuretic effect). }\end{array}$ & 30 days & $\begin{array}{l}\text { - Safe therapy; } \\
\text { - } \downarrow \text { Serum creatinine } \\
\text { - } \uparrow \text { Diuresis, } \downarrow \text { weight } \\
\text { - } \downarrow \text { CV death at } 30 \text { days } \\
\text { - Improved dyspnea and } \\
\text { clinical status }\end{array}$ \\
\hline Deftereos et al., 2014 & $\begin{array}{l}\text { Single-center, } \\
\text { prospective, } \\
\text { double-blinded, } \\
\text { placebo-controlled } \\
\text { study }\end{array}$ & $\begin{array}{l}267 \text { Patients with stable } \\
\text { CHF and systolic } \\
\text { dysfunction (EF } \leq 40 \%) \\
\text { (Greece) with mean LVEF of } \\
<35 \%\end{array}$ & $\begin{array}{l}\text { Intervention group }(n=134) \text { : } \\
\text { oral colchicine } 0.5 \mathrm{mg} \text { twice } \\
\text { daily (once daily if } \\
\text { weight }<60 \mathrm{~kg} \text { ) for } 6 \text { months } \\
\text { Placebo group ( } n=133 \text { ) }\end{array}$ & $\begin{array}{l}\text { Microtubule inhibitor with } \\
\text { anti-inflammatory properties: } \\
\text { inhibits NLRP3 inflammasome } \\
\text { activation; disruption of } \\
\text { leukocyte functions. }\end{array}$ & 6 months & $\begin{array}{l}\text { - Safe use of colchicine; } \\
\text { - } \downarrow \text { hsCRP, IL-6 } \\
\text { - No effect on patient functiona } \\
\text { status, death or hospital stay }\end{array}$ \\
\hline $\begin{array}{l}\text { EXACT-HF study (Xanthine } \\
\text { Oxidase Inhibition for } \\
\text { Hyperuricemic Heart Failure } \\
\text { Patients) } \\
\text { (Givertz et al., 2015) }\end{array}$ & $\begin{array}{l}\text { Multi-center, 1:1 } \\
\text { randomized, } \\
\text { double-blind, } \\
\text { placebo-controlled }\end{array}$ & $\begin{array}{l}253 \text { II-IV NYHA class } \\
\text { ischemic and dilated } \\
\text { cardiomyopathy HFrEF } \\
\text { patients (LVEF } \leq 40 \% \text { ) and } \\
\text { elevated serum UA levels } \\
\text { ( } \geq 9.5 \mathrm{mg} / \mathrm{dL} \text { ) (various } \\
\text { centers in United States } \\
\text { and Canada) }\end{array}$ & $\begin{array}{l}\text { Allopurinol was given for } \\
24 \text { weeks starting with } 300 \mathrm{mg} \\
\text { by mouth once daily for } 1 \text { week, } \\
\text { and if tolerated, increased to } \\
600 \text { mg daily. Patients unable } \\
\text { to tolerate } 600 \mathrm{mg} \text { were } \\
\text { maintained on } 300 \mathrm{mg} \text {. }\end{array}$ & $\begin{array}{l}\text { Xanthine oxidase inhibitor; besides } \\
\text { urate lowering, } \downarrow \text { oxidative stress } \\
\text { and inflammatory mediators. }\end{array}$ & 6 months & $\begin{array}{l}\text { - Failed to improve clinical } \\
\text { status, exercise capacity, } \\
\text { quality of life, or LVEF at } \\
24 \text { weeks }\end{array}$ \\
\hline
\end{tabular}

ADHF, acute decompensated heart failure; CAMP, cyclic Adenosine Monophosphate; CHF, chronic heart failure; CRP, C-reactive protein; CV, cardiovascular; HFrEF, heart failure with reduced ejection fraction; hsCRP, high sensitive C reactive protein; IL-6, interleukin 6; LVEF, left ventricular ejection fraction; MCP-1, Monocyte chemoattractant Protein-1; NLRP3, NOD-. LRR-and pyrin domain-containing protein 3; NYHA, New York Heart Association; PUFA, polyunsaturated fatty acids; QD, once a day; SPMs, specialized proresolving mediators; sICAM-1, soluble intercellular adhesion molecule-1; TID, three times daily; TNF- $\alpha$, Tumor necrosis factor alpha. 
(anti-TNF drug, inhibition of neutrophils), as well as matrix stabilizing and antifibrotic properties could contribute to the beneficial effects of thalidomide in HF, a potential risk of harmful effects on the myocardium should also be considered. Our knowledge of its mechanisms of action in chronic HF is limited, awaiting further elucidation in forthcoming studies, as well as the test of newer thalidomide analogs such as lenalidomide, which are more potent and have a more favorable toxicity profile (Aukrust et al., 2007). Interestingly, a meta-analysis of trials with pentoxifylline, a medication with a larger therapeutic index and multiple uses, like limb ischemia or alcoholic hepatitis, seems to suggest a significant nearly fourfold decrease in allcause mortality in human HF (Champion et al., 2014), even though small trials did not show reduction of mortality. Thus, this xanthinic base with vasodilatatory, anti-inflammatory, antiapoptotic, and rheological properties (Zhang et al., 2004) deserves further exploration in HF. Treatment with colchicine, a well-known alkaloid with potent anti-inflammatory properties, has demonstrated promising results for the secondary prevention of CVD (Webb and Barry, 2020), although it did not provide a benefit in death or HF hospitalization, despite a reduction in inflammatory markers (Deftereos et al., 2014). Thus, the Colchicine in STEMI Patients Study (COVERT-MI), an ongoing confirmative prospective, multicenter, randomized, double-blind trial, is testing whether a short course oral treatment with colchicine versus placebo decreases myocardial injury in patients presenting with STEMI (Bresson et al., 2021), since add-on treatment of coronary artery disease patients already proved to reduce inflammatory biomarkers (Sethuramalingam et al., 2021). The anti-inflammatory effects of methotrexate seem to depend on adenosine receptor stimulation by endogenously generated adenosine (Montesinos et al., 2000). Adenosine is a potent immunomodulatory agent and its receptors activation also induces vasodilation, inhibition of sympathetic neurotransmitter release and induction of ischemic preconditioning, independently of adenosine immunomodulatory effects (Rongen et al., 1997). This could explain why preliminary studies demonstrated cardioprotective effects of raised adenosine concentrations in HF patients (Kitakaze et al., 1998). However, once again, there is still no sufficient data yet to generalize the prevention of incidence of cardiovascular events, demonstrated for rheumatoid arthritis patients, in order to treat patients with coronary heart disease (Sun et al., 2021). Glucocorticoid administration is not recommended routinely in the international guidelines in patients with HF because of its related sodium and fluid retention caused by the stimulation of sodium reabsorption at the level of renal tubules (Ponikowski et al., 2016). On the other hand, few studies have demonstrated that glucocorticoids can enhance natriuresis in HF patients (Liu et al., 2006, 2007; Zhang et al., 2008; Massari et al., 2012), probably by causing vasodilation of the afferent and efferent arterioles and consequently increasing renal blood flow mediated by $\mathrm{NO}$ and prostaglandins restricted to kidney bed (De Matteo and May, 1997; de Matteo and May, 1999), as well as by up-regulating ANP synthesis and receptors (Garcia et al., 1985; Lanier-Smith and Currie, 1990). So, larger randomized clinical trials must assure safety and clinical results of COPE-ADHF with enough evidence to promote re-discussion of the main consensus.

Major trials targeting important inflammatory mediators of $\mathrm{HF}$ or involving other anti-inflammatory/immunomodulatory strategies in HF are summarized in Tables 1, 2. Most of them were conducted in HFrEF patients, except for the ongoing study with MPO and DHART trials which were specifically designed for HFpEF patients. Contrary to HFrEF, to date, no treatment has been shown to reduce morbidity and mortality in patients with HFpEF (Borlaug, 2020). Although candesartan (Yusuf et al., 2003) and sacubitril/valsartan (Solomon et al., 2020) appear to reduce hospitalizations in patients with LVEF > 40 or $45 \%$, respectively, no randomized clinical trial convincingly reached its primary endpoint. Treating hypervolemia (Adamson et al., 2014) and the mineralocorticoid antagonist spironolactone (Pitt et al., 2014) seemed to produce similar results, with no effect on mortality. On the other hand, nebivolol in SENIORS trial showed promising effects on reduction of cardiovascular mortality but the group of HFpEF considered had LVEF > 35\%, including only $15 \%$ with a LVEF > 50\% (van Veldhuisen et al., 2009). Therefore, the effect of NO-GMPc pathway was also explored but also failed to improve exercise capacity and quality of life (Redfield et al., 2015; Borlaug et al., 2018; Armstrong et al., 2020). Recently, novel evidence emerged strengthening the inflammatory paradigm and reinforcing research for anti-cytokine biological therapy in HFpEF (Paulus and Zile, 2021). For example, higher IL-6 levels were demonstrated to be associated with an increased risk of developing HFpEF (Chia et al., 2021) and circulating levels of TNF- $\alpha$ receptor 2 were shown to be increased in association with the degree of diastolic dysfunction in patients with HFpEF but not HFrEF (Putko et al., 2014). Also, (anti-inflammatory) high density lipoprotein cholesterol/(inflammatory) CRP ratio was shown to be a useful marker for prognostication and correlated with echocardiographic parameters in HFpEF patients (Yano et al., 2021). Moreover, a recent report suggested that the deletion of resolution sensor ALX/FPR2 is associated with the development of diastolic dysfunction related with obesity in mice with HFpEF (Tourki et al., 2020), supporting the concept of nonresolving inflammation in HFpEF (Tourki and Halade, 2021). Besides all this, until now, anti-inflammatory therapies in HFpEF were negative (Murphy et al., 2020), including D-HART2 which failed to improve exercise capacity demonstrated in the pilot study despite lowering CRP and NT-pro-BNP in these patients (Gullestad et al., 2001a; Van Tassell et al., 2018).

\section{CONCLUSION}

Since the recognition by Levine et al. (1990) of elevated TNF$\alpha$ in CHF patients, there has been a growing body of evidence on the association of a myriad of cytokines and chemokines with HFrEF but more recently this has also been demonstrated in the entire clinical spectrum of HF like HFpEF and even in AHF and CS (Mann, 2015). The progression of HF was believed to be due, along with neurohormonal activation, to a sustained inflammatory signaling - chronic para-inflammation - a theory that became collectively known as the "cytokine hypothesis" 
(Seta et al., 1996). Major inflammatory players in HF include TNF- $\alpha$, IL-1, IL-6, IL-8, IL-10, MPO, iNOS, and CRP, to which experimental and clinical attempts have been directed to target or modulate them. However, the optimal approach seems far to be completed, underscoring the complexity of anti-inflammatory strategies. Although disappointing, negative results do not necessarily argue against the cytokine hypothesis (Dutka et al., 2020). If, in one hand, isolated high intensity anti-TNF- $\alpha$ strategies seem to be rejected, anti-IL-1 and antiIL-6 therapeutics remain to be explored and individualized. While a new therapeutic strategy such as MPO inhibition is currently being tested, immunomodulators like pentoxyfilline, thalidomide, n-3-PUFAs, glucocorticoids or colchicine, already evaluated in preliminary studies, also deserve further larger research. Trials based on serum CRP and UA have underpinned them as biomarkers and probably not as therapeutic targets. In fact, one of the main conclusions we can get from this cytokine hypothesis history is that probably the future will be to tailor the therapeutics according to an inflammatory profile (Van Linthout and Tschope, 2019) which will require a better knowledge of the players acting on HF immunopathogenesis in order to improve immunomodulatory treatment (Bajaj et al., 2020), or alternatively

\section{REFERENCES}

Abbate, A., Toldo, S., Marchetti, C., Kron, J., Van Tassell, B. W., and Dinarello, C. A. (2020). Interleukin-1 and the inflammasome as therapeutic targets in cardiovascular disease. Circ. Res. 126, 1260-1280. doi: 10.1161/CIRCRESAHA. 120.315937

Abbate, A., Van Tassell, B. W., Biondi-Zoccai, G., Kontos, M. C., Grizzard, J. D., Spillman, D. W., et al. (2013). Effects of interleukin-1 blockade with anakinra on adverse cardiac remodeling and heart failure after acute myocardial infarction [from the Virginia Commonwealth University-Anakinra Remodeling Trial (2) (VCU-ART2) pilot study]. Am. J. Cardiol. 111, 1394-1400. doi: 10.1016/j. amjcard.2013.01.287

Adamo, L., Rocha-Resende, C., Prabhu, S. D., and Mann, D. L. (2020). Reappraising the role of inflammation in heart failure. Nat. Rev. Cardiol. 17, 269-285. doi: 10.1038/s41569-019-0315-x

Adamson, P. B., Abraham, W. T., Bourge, R. C., Costanzo, M. R., Hasan, A., Yadav, C., et al. (2014). Wireless pulmonary artery pressure monitoring guides management to reduce decompensation in heart failure with preserved ejection fraction. Circ. Heart Fail. 7, 935-944. doi: 10.1161/CIRCHEARTFAILURE.113. 001229

Ali, M., Pulli, B., Courties, G., Tricot, B., Sebas, M., Iwamoto, Y., et al. (2016). Myeloperoxidase inhibition improves ventricular function and remodeling after experimental myocardial infarction. JACC Basic Transl. Sci. 1, 633-643. doi: 10.1016/j.jacbts.2016.09.004

Altara, R., Ghali, R., Mallat, Z., Cataliotti, A., Booz, G. W., and Zouein, F. A. (2018). Conflicting vascular and metabolic impact of the IL-33/sST2 axis. Cardiovasc. Res. 114, 1578-1594. doi: 10.1093/cvr/cvy166

Anand, I. S., Latini, R., Florea, V. G., Kuskowski, M. A., Rector, T., Masson, S., et al. (2005). C-reactive protein in heart failure: prognostic value and the effect of valsartan. Circulation 112, 1428-1434. doi: 10.1161/CIRCULATIONAHA.104. 508465

Anker, S. D., Doehner, W., Rauchhaus, M., Sharma, R., Francis, D., Knosalla, C., et al. (2003). Uric acid and survival in chronic heart failure: validation and application in metabolic, functional, and hemodynamic staging. Circulation 107, 1991-1997. doi: 10.1161/01.CIR.0000065637.10517.A0

Apostolakis, S., Vogiatzi, K., Amanatidou, V., and Spandidos, D. A. (2009). Interleukin 8 and cardiovascular disease. Cardiovasc. Res. 84, 353-360. doi: $10.1093 / \mathrm{cvr} / \mathrm{cvp} 241$ to promote the resolution of inflammation which remains scarcely studied in human HF (Reina-Couto et al., 2014, 2016; Chiurchiu et al., 2019).

\section{AUTHOR CONTRIBUTIONS}

MR-C and TS conceived and wrote the manuscript. PP-T, JQ-S, and CS-P wrote the manuscript. TS and AA-T supervised and reviewed the manuscript. All the authors contributed to the article and approved the submitted version.

\section{FUNDING}

This work was supported by FEDER funds via COMPETE, Portugal 2020 - Operational Programme for Competitiveness and Internationalization (POCI) (POCI-01-0145-FEDER032188) and by national funds through the Portuguese Foundation for Science and Technology (FCT) (RIFF-HEART project: PTDC/MEC-CAR/32188/2017). CS-P is a recipient of a Ph.D. fellowship from FCT (UI/BD/150816/2020).

Armstrong, P. W., Lam, C. S. P., Anstrom, K. J., Ezekowitz, J., Hernandez, A. F., O'Connor, C. M., et al. (2020). Effect of Vericiguat vs Placebo on quality of life in patients with heart failure and preserved ejection fraction: The VITALITYHFpEF randomized clinical trial. JAMA 324, 1512-1521. doi: 10.1001/jama. 2020.15922

Askari, A. T., Brennan, M. L., Zhou, X., Drinko, J., Morehead, A., Thomas, J. D., et al. (2003). Myeloperoxidase and plasminogen activator inhibitor 1 play a central role in ventricular remodeling after myocardial infarction. J. Exp. Med. 197, 615-624. doi: 10.1084/jem.20021426

Aukrust, P., Yndestad, A., Damas, J. K., Ueland, T., Oie, E., and Gullestad, L. (2007). Potential mechanisms of benefit with thalidomide in chronic heart failure. Am. J. Cardiovasc. Drugs 7, 127-134. doi: 10.2165/00129784-20070702000004

Bailey, A., Pope, T. W., Moore, S. A., and Campbell, C. L. (2007). The tragedy of TRIUMPH for nitric oxide synthesis inhibition in cardiogenic shock: where do we go from here? Am. J. Cardiovasc. Drugs 7, 337-345. doi: 10.2165/00129784200707050-00003

Bajaj, N. S., Gupta, K., Gharpure, N., Pate, M., Chopra, L., Kalra, R., et al. (2020). Effect of immunomodulation on cardiac remodelling and outcomes in heart failure: a quantitative synthesis of the literature. ESC Heart Fail 7, 1319-1330. doi: 10.1002/ehf2.12681

Bartekova, M., Radosinska, J., Jelemensky, M., and Dhalla, N. S. (2018). Role of cytokines and inflammation in heart function during health and disease. Heart Fail Rev 23, 733-758. doi: 10.1007/s10741-018-9716-x

Bassuk, S. S., Rifai, N., and Ridker, P. M. (2004). High-sensitivity C-reactive protein: clinical importance. Curr. Probl. Cardiol. 29, 439-493.

Berry, M. F., Woo, Y. J., Pirolli, T. J., Bish, L. T., Moise, M. A., Burdick, J. W., et al. (2004). Administration of a tumor necrosis factor inhibitor at the time of myocardial infarction attenuates subsequent ventricular remodeling. J. Heart Lung Transplant. 23, 1061-1068. doi: 10.1016/j.healun.2004.06.021

Bhatt, D. L., Steg, P. G., Miller, M., Brinton, E. A., Jacobson, T. A., Ketchum, S. B., et al. (2019). Cardiovascular risk reduction with icosapent ethyl for hypertriglyceridemia. N. Engl. J. Med. 380, 11-22. doi: 10.1056/ NEJMoa1812792

Bian, R. T., Wang, Z. T., and Li, W. Y. (2021). Immunoadsorption treatment for dilated cardiomyopathy: A PRISMA-compliant systematic review and meta-analysis. Medicine (Baltimore) 100:e26475. doi: 10.1097/MD.0000000000026475 
Bilusic, M., Heery, C. R., Collins, J. M., Donahue, R. N., Palena, C., Madan, R. A., et al. (2019). Phase I trial of HuMax-IL8 (BMS-986253), an anti-IL-8 monoclonal antibody, in patients with metastatic or unresectable solid tumors. J. Immunother. Cancer 7:240. doi: 10.1186/s40425-019-0706-X

Block, R. C., Liu, L., Herrington, D. M., Huang, S., Tsai, M. Y., O’Connell, T. D., et al. (2019). Predicting risk for incident heart failure with omega-3 fatty acids: From MESA. JACC Heart Fail. 7, 651-661. doi: 10.1016/j.jchf.2019.03.008

Boisot, S., Beede, J., Isakson, S., Chiu, A., Clopton, P., Januzzi, J., et al. (2008). Serial sampling of ST2 predicts 90-day mortality following destabilized heart failure. J. Card Fail. 14, 732-738. doi: 10.1016/j.cardfail.2008.06.415

Borlaug, B. A. (2020). Evaluation and management of heart failure with preserved ejection fraction. Nat. Rev. Cardiol. 17, 559-573. doi: 10.1038/s41569-0200363-2

Borlaug, B. A., Anstrom, K. J., Lewis, G. D., Shah, S. J., Levine, J. A., Koepp, G. A., et al. (2018). Effect of inorganic nitrite vs placebo on exercise capacity among patients with heart failure with preserved ejection fraction: The INDIE-HFpEF randomized clinical trial. JAMA 320, 1764-1773. doi: 10.1001/jama.2018.14852

Borovac, J. A., Glavas, D., Susilovic Grabovac, Z., Supe Domic, D., Stanisic, L., D'Amario, D., et al. (2020). Circulating sST2 and catestatin levels in patients with acute worsening of heart failure: a report from the CATSTAT-HF study. ESC Heart Fail 7, 2818-2828. doi: 10.1002/ehf2.12882

Bozkurt, B., Torre-Amione, G., Warren, M. S., Whitmore, J., Soran, O. Z., Feldman, A. M., et al. (2001). Results of targeted anti-tumor necrosis factor therapy with etanercept (ENBREL) in patients with advanced heart failure. Circulation 103, 1044-1047. doi: 10.1161/01.cir.103.8.1044

Braunwald, E. (2013). Heart failure. JACC Heart Fail. 1, 1-20. doi: 10.1016/j.jchf. 2012.10.002

Bresson, D., Roubille, F., Prieur, C., Biere, L., Ivanes, F., Bouleti, C., et al. (2021). Colchicine for left ventricular infarct size reduction in acute myocardial infarction: A Phase II, multicenter, randomized, double-blinded, placebocontrolled study protocol - The COVERT-MI study. Cardiology 146, 151-160. doi: $10.1159 / 000512772$

Buckley, L. F., Carbone, S., Trankle, C. R., Canada, J. M., Erdle, C. O., Regan, J. A., et al. (2018). Effect of interleukin-1 blockade on left ventricular systolic performance and work: A post hoc pooled analysis of 2 clinical trials. J. Cardiovasc. Pharmacol. 72, 68-70. doi: 10.1097/FJC.0000000000000591

Calabro, P., Willerson, J. T., and Yeh, E. T. (2003). Inflammatory cytokines stimulated C-reactive protein production by human coronary artery smooth muscle cells. Circulation 108, 1930-1932. doi: 10.1161/01.CIR.0000096055. 62724.C5

Carracedo, M., Artiach, G., Arnardottir, H., and Back, M. (2019). The resolution of inflammation through omega-3 fatty acids in atherosclerosis, intimal hyperplasia, and vascular calcification. Semin. Immunopathol. 41, 757-766. doi: 10.1007/s00281-019-00767-y

Castillo, E. C., Vazquez-Garza, E., Yee-Trejo, D., Garcia-Rivas, G., and TorreAmione, G. (2020). What is the role of the inflammation in the pathogenesis of heart failure? Curr. Cardiol. Rep. 22:139. doi: 10.1007/s11886-020-01382-2

Cavalli, G., Foppoli, M., Cabrini, L., Dinarello, C. A., Tresoldi, M., and Dagna, L. (2017). Interleukin-1 receptor blockade rescues myocarditis-associated endstage heart failure. Front. Immunol. 8:131. doi: 10.3389/fimmu.2017.00131

Champion, S., Lapidus, N., Cherie, G., Spagnoli, V., Oliary, J., and Solal, A. C. (2014). Pentoxifylline in heart failure: a meta-analysis of clinical trials Cardiovasc. Ther. 32, 159-162. doi: 10.1111/1755-5922.12076

Chen, D., Assad-Kottner, C., Orrego, C., and Torre-Amione, G. (2008). Cytokines and acute heart failure. Crit. Care Med. 36, S9-S16. doi: 10.1097/01.CCM. 0000297160.48694 .90

Chen, W. Y., Hong, J., Gannon, J., Kakkar, R., and Lee, R. T. (2015). Myocardial pressure overload induces systemic inflammation through endothelial cell IL33. Proc. Natl. Acad. Sci. U S A 112, 7249-7254. doi: 10.1073/pnas.1424236112

Chia, Y. C., Kieneker, L. M., van Hassel, G., Binnenmars, S. H., Nolte, I. M., van Zanden, J. J., et al. (2021). Interleukin 6 and development of heart failure with preserved ejection fraction in the general population. J. Am. Heart Assoc. 10:e018549. doi: 10.1161/JAHA.120.018549

Chioncel, O., Parissis, J., Mebazaa, A., Thiele, H., Desch, S., Bauersachs, J., et al. (2020). Epidemiology, pathophysiology and contemporary management of cardiogenic shock - a position statement from the Heart Failure Association of the European Society of Cardiology. Eur. J. Heart Fail. 22, 1315-1341. doi: 10.1002/ejhf.1922
Chiurchiu, V., Leuti, A., Saracini, S., Fontana, D., Finamore, P., Giua, R., et al. (2019). Resolution of inflammation is altered in chronic heart failure and entails a dysfunctional responsiveness of T lymphocytes. FASEB J. 33, 909-916. doi: 10.1096/fj.201801017R

Choi, Y. S., Choi, H. J., Min, J. K., Pyun, B. J., Maeng, Y. S., Park, H., et al. (2009). Interleukin-33 induces angiogenesis and vascular permeability through ST2/TRAF6-mediated endothelial nitric oxide production. Blood 114, 31173126. doi: 10.1182/blood-2009-02-203372

Chung, E. S., Packer, M., Lo, K. H., Fasanmade, A. A., Willerson, J. T., and Anti-Tnf Therapy Against Congestive Heart Failure Investigators. (2003). Randomized, double-blind, placebo-controlled, pilot trial of infliximab, a chimeric monoclonal antibody to tumor necrosis factor-alpha, in patients with moderate-to-severe heart failure: results of the anti-TNF Therapy Against Congestive Heart Failure (ATTACH) trial. Circulation 107, 3133-3140. doi: 10.1161/01.CIR.0000077913.60364.D2

Cinelli, M. A., Do, H. T., Miley, G. P., and Silverman, R. B. (2020). Inducible nitric oxide synthase: Regulation, structure, and inhibition. Med. Res. Rev. 40, 158-189. doi: 10.1002/med.21599

Correa, S., Pena-Esparragoza, J. K., Scovner, K. M., Waikar, S. S., and Mc Causland, F. R. (2020). Myeloperoxidase and the risk of CKD progression, cardiovascular disease, and death in the Chronic Renal Insufficiency Cohort (CRIC) Study. Am. J. Kidney Dis. 76, 32-41. doi: 10.1053/j.ajkd.2019. 09.006

Costa, S., Reina-Couto, M., Albino-Teixeira, A., and Sousa, T. (2016). Statins and oxidative stress in chronic heart failure. Rev. Port Cardiol. 35, 41-57. doi: 10.1016/j.repc.2015.09.006

Cotter, G., Felker, G. M., Adams, K. F., Milo-Cotter, O., and O'Connor, C. M. (2008). The pathophysiology of acute heart failure-is it all about fluid accumulation? Am. Heart J. 155, 9-18. doi: 10.1016/j.ahj.2006.02. 038

Cotter, G., Kaluski, E., Blatt, A., Milovanov, O., Moshkovitz, Y., Zaidenstein, R., et al. (2000). L-NMMA (a nitric oxide synthase inhibitor) is effective in the treatment of cardiogenic shock. Circulation 101, 1358-1361. doi: 10.1161/01. cir.101.12.1358

Cotter, G., Kaluski, E., Milo, O., Blatt, A., Salah, A., Hendler, A., et al. (2003). LINCS: L-NAME (a NO synthase inhibitor) in the treatment of refractory cardiogenic shock: a prospective randomized study. Eur. Heart J. 24, 12871295. doi: 10.1016/s0195-668x(03)00193-3

Cotton, J. M., Kearney, M. T., and Shah, A. M. (2002). Nitric oxide and myocardial function in heart failure: friend or foe? Heart 88, 564-566. doi: 10.1136/heart. 88.6.564

Csato, V., Peto, A., Fulop, G. A., Rutkai, I., Pasztor, E. T., Fagyas, M., et al. (2015). Myeloperoxidase evokes substantial vasomotor responses in isolated skeletal muscle arterioles of the rat. Acta Physiol. (Oxf) 214, 109-123. doi: 10.1111/apha. 12488

Cuinet, J., Garbagnati, A., Rusca, M., Yerly, P., Schneider, A. G., Kirsch, M., et al. (2020). Cardiogenic shock elicits acute inflammation, delayed eosinophilia, and depletion of immune cells in most severe cases. Sci. Rep. 10:7639. doi: 10.1038/ s41598-020-64702-0

Dallos, M. (2020). National Library of Medicine (U.S.). Anti-Interleukin-8 (AntiIL-8) for Patients With COVID-19. Identifier NCT04347226. Available online at: https://clinicaltrials.gov/ct2/show/NCT04347226

Damas, J. K., Gullestad, L., Ueland, T., Solum, N. O., Simonsen, S., Froland, S. S., et al. (2000). CXC-chemokines, a new group of cytokines in congestive heart failure-possible role of platelets and monocytes. Cardiovasc. Res. 45, 428-436. doi: 10.1016/s0008-6363(99)00262-x

De Gennaro, L., Brunetti, N. D., Montrone, D., De Rosa, F., Cuculo, A., and Di Biase, M. (2012). Subacute inflammatory activation in subjects with acute coronary syndrome and left ventricular dysfunction. Inflammation 35, 363-370. doi: 10.1007/s10753-011-9326-4

De Matteo, R., and May, C. N. (1997). Glucocorticoid-induced renal vasodilatation is mediated by a direct renal action involving nitric oxide. Am. J. Physiol. 273, R1972-R1979. doi: 10.1152/ajpregu.1997.273.6.R1972

de Matteo, R., and May, C. N. (1999). Inhibition of prostaglandin and nitric oxide synthesis prevents cortisol-induced renal vasodilatation in sheep. Am. J. Physiol. 276, R1125-R1131. doi: 10.1152/ajpregu.1999.276.4.R1125

Debrunner, M., Schuiki, E., Minder, E., Straumann, E., Naegeli, B., Mury, R., et al. (2008). Proinflammatory cytokines in acute myocardial infarction with and 
without cardiogenic shock. Clin. Res. Cardiol. 97, 298-305. doi: 10.1007/s00392007-0626-5

Deftereos, S., Giannopoulos, G., Panagopoulou, V., Bouras, G., Raisakis, K., Kossyvakis, C., et al. (2014). Anti-inflammatory treatment with colchicine in stable chronic heart failure: A prospective, randomized study. JACC Heart Fail. 2, 131-137. doi: 10.1016/j.jchf.2013.11.006

Demyanets, S., Kaun, C., Pentz, R., Krychtiuk, K. A., Rauscher, S., Pfaffenberger, S., et al. (2013). Components of the interleukin-33/ST2 system are differentially expressed and regulated in human cardiac cells and in cells of the cardiac vasculature. J. Mol. Cell. Cardiol. 60, 16-26. doi: 10.1016/j.yjmcc.2013.03.020

Demyanets, S., Konya, V., Kastl, S. P., Kaun, C., Rauscher, S., Niessner, A., et al. (2011). Interleukin-33 induces expression of adhesion molecules and inflammatory activation in human endothelial cells and in human atherosclerotic plaques. Arterioscler. Thromb. Vasc. Biol. 31, 2080-2089. doi: 10.1161/ATVBAHA.111.231431

Desai, A. S., and Stevenson, L. W. (2012). Rehospitalization for heart failure: predict or prevent? Circulation 126, 501-506. doi: 10.1161/CIRCULATIONAHA.112. 125435

Deswal, A., Bozkurt, B., Seta, Y., Parilti-Eiswirth, S., Hayes, F. A., Blosch, C., et al. (1999). Safety and efficacy of a soluble P75 tumor necrosis factor receptor (Enbrel, etanercept) in patients with advanced heart failure. Circulation 99, 3224-3226. doi: 10.1161/01.cir.99.25.3224

Dhingra, S., Bagchi, A. K., Ludke, A. L., Sharma, A. K., and Singal, P. K. (2011). Akt regulates IL-10 mediated suppression of TNFalpha-induced cardiomyocyte apoptosis by upregulating Stat3 phosphorylation. PLoS One 6:e25009. doi: 10. 1371/journal.pone.0025009

Dhingra, S., Sharma, A. K., Arora, R. C., Slezak, J., and Singal, P. K. (2009). IL-10 attenuates TNF-alpha-induced NF kappaB pathway activation and cardiomyocyte apoptosis. Cardiovasc. Res. 82, 59-66. doi: 10.1093/cvr/cvp040

Dinarello, C. A., Novick, D., Kim, S., and Kaplanski, G. (2013). Interleukin-18 and IL-18 binding protein. Front. Immunol. 4:289. doi: 10.3389/fimmu.2013.00289

Dixon, D. L., Griggs, K. M., Bersten, A. D., and De Pasquale, C. G. (2011). Systemic inflammation and cell activation reflects morbidity in chronic heart failure. Cytokine 56, 593-599. doi: 10.1016/j.cyto.2011.08.029

Dominguez-Rodriguez, A., Abreu-Gonzalez, P., Garcia-Gonzalez, M., and Ferrer, J. (2006). Prognostic value of interleukin-8 as a predictor of heart failure in patients with myocardial infarction and percutaneous intervention. Int. J. Cardiol. 111, 158-160. doi: 10.1016/j.ijcard.2005.05.063

Donovan, C., and Hansbro, P. M. (2020). IL-33 in chronic respiratory disease: from preclinical to clinical studies. ACS Pharmacol. Transl. Sci. 3, 56-62. doi: 10.1021/acsptsci.9b00099

Dutka, M., Bobinski, R., Ulman-Wlodarz, I., Hajduga, M., Bujok, J., Pajak, C., et al. (2020). Various aspects of inflammation in heart failure. Heart Fail. Rev. 25, 537-548. doi: 10.1007/s10741-019-09875-1

Dzavík, V., Cotter, G., Reynolds, H. R., Alexander, J. H., Ramanathan, K., Stebbins, A. L., et al. (2007). Effect of nitric oxide synthase inhibition on haemodynamics and outcome of patients with persistent cardiogenic shock complicating acute myocardial infarction: a phase II dose-ranging study. Eur. Heart J. 28, 11091116. doi: 10.1093/eurheartj/ehm075

Espriella, R., Bayes-Genis, A., Revuelta-Lo, P. E., Minana, G., Santas, E., Llacer, P., et al. (2021). Soluble ST2 and diuretic efficiency in acute heart failure and concomitant renal dysfunction. J. Card Fail. 27, 427-434. doi: 10.1016/j.cardfail. 2020.10.002

Everett, B. M., Cornel, J. H., Lainscak, M., Anker, S. D., Abbate, A., Thuren, T., et al. (2019). Anti-inflammatory therapy with canakinumab for the prevention of hospitalization for heart failure. Circulation 139, 1289-1299. doi: 10.1161/ CIRCULATIONAHA.118.038010

Farag, M., Mabote, T., Shoaib, A., Zhang, J., Nabhan, A. F., Clark, A. L., et al. (2015). Hydralazine and nitrates alone or combined for the management of chronic heart failure: A systematic review. Int. J. Cardiol. 196, 61-69. doi: 10.1016/j.ijcard.2015.05.160

Fichtlscherer, S., Rossig, L., Breuer, S., Vasa, M., Dimmeler, S., and Zeiher, A. M. (2001). Tumor necrosis factor antagonism with etanercept improves systemic endothelial vasoreactivity in patients with advanced heart failure. Circulation 104, 3023-3025. doi: 10.1161/hc5001.101749

Finkel, M. S., Oddis, C. V., Jacob, T. D., Watkins, S. C., Hattler, B. G., and Simmons, R. L. (1992). Negative inotropic effects of cytokines on the heart mediated by nitric oxide. Science 257, 387-389. doi: 10.1126/science. 1631560
Frangogiannis, N. G. (2015). Interleukin-1 in cardiac injury, repair, and remodeling: pathophysiologic and translational concepts. Discoveries (Craiova) 3:e41. doi: 10.15190/d.2015.33

Gabay, C. (2006). Interleukin-6 and chronic inflammation. Arthritis. Res. Ther. 8:S3. doi: $10.1186 /$ ar1917

Gabay, C., Fautrel, B., Rech, J., Spertini, F., Feist, E., Kotter, I., et al. (2018). Openlabel, multicentre, dose-escalating phase II clinical trial on the safety and efficacy of tadekinig alfa (IL-18BP) in adult-onset Still's disease. Ann. Rheum. Dis. 77, 840-847. doi: 10.1136/annrheumdis-2017-212608

Gan, L. M., Lagerstrom-Fermer, M., Ericsson, H., Nelander, K., Lindstedt, E. L., Michaelsson, E., et al. (2019). Safety, tolerability, pharmacokinetics and effect on serum uric acid of the myeloperoxidase inhibitor AZD4831 in a randomized, placebo-controlled, phase I study in healthy volunteers. Br. J. Clin. Pharmacol. 85, 762-770. doi: 10.1111/bcp.13855

Garcia, R., Debinski, W., Gutkowska, J., Kuchel, O., Thibault, G., Genest, J., et al. (1985). Gluco- and mineralocorticoids may regulate the natriuretic effect and the synthesis and release of atrial natriuretic factor by the rat atria in vivo. Biochem. Biophys. Res. Commun. 131, 806-814. doi: 10.1016/0006-291x(85) 91311-7

Geppert, A., Dorninger, A., Delle-Karth, G., Zorn, G., Heinz, G., and Huber, K. (2006). Plasma concentrations of interleukin-6, organ failure, vasopressor support, and successful coronary revascularization in predicting 30-day mortality of patients with cardiogenic shock complicating acute myocardial infarction. Crit. Care Med. 34, 2035-2042. doi: 10.1097/01.CCM.0000228919. 33620.D9

Ghali, R., Altara, R., Louch, W. E., Cataliotti, A., Mallat, Z., Kaplan, A., et al. (2018). IL-33 (Interleukin 33)/sST2 axis in hypertension and heart failure. Hypertension 72, 818-828. doi: 10.1161/HYPERTENSIONAHA.118.11157

Givertz, M. M., Anstrom, K. J., Redfield, M. M., Deswal, A., Haddad, H., Butler, J., et al. (2015). Effects of xanthine oxidase inhibition in hyperuricemic heart failure patients: The xanthine oxidase inhibition for hyperuricemic Heart Failure patients (EXACT-HF) study. Circulation 131, 1763-1771. doi: 10.1161/ CIRCULATIONAHA.114.014536

Glezeva, N., and Baugh, J. A. (2014). Role of inflammation in the pathogenesis of heart failure with preserved ejection fraction and its potential as a therapeutic target. Heart Fail. Rev. 19, 681-694. doi: 10.1007/s10741-013-9405-8

Gong, K., Zhang, Z., Sun, X., Zhang, X., Li, A., Yan, J., et al. (2006). The nonspecific anti-inflammatory therapy with methotrexate for patients with chronic heart failure. Am. Heart J. 151, 62-68. doi: 10.1016/j.ahj.2005.02.040

Gotsman, I., Keren, A., Lotan, C., and Zwas, D. R. (2012). Changes in uric acid levels and allopurinol use in chronic heart failure: association with improved survival. J. Card Fail. 18, 694-701. doi: 10.1016/j.cardfail.2012.06. 528

Griselli, M., Herbert, J., Hutchinson, W. L., Taylor, K. M., Sohail, M., Krausz, T., et al. (1999). C-reactive protein and complement are important mediators of tissue damage in acute myocardial infarction. J. Exp. Med. 190, 1733-1740. doi: $10.1084 /$ jem.190.12.1733

Gullestad, L., Ueland, T., Brunsvig, A., Kjekshus, J., Simonsen, S., Froland, S. S., et al. (2001b). Effect of metoprolol on cytokine levels in chronic heart failure-a substudy in the metoprolol controlled-release randomised intervention trial in heart failure (MERIT-HF). Am. Heart J. 141, 418-421. doi: 10.1067/mhj.2001. 112785

Gullestad, L., Aass, H., Fjeld, J. G., Wikeby, L., Andreassen, A. K., Ihlen, H., et al. (2001a). Immunomodulating therapy with intravenous immunoglobulin in patients with chronic heart failure. Circulation 103, 220-225. doi: 10.1161/01. cir.103.2.220

Gullestad, L., Orn, S., Dickstein, K., Eek, C., Edvardsen, T., Aakhus, S., et al. (2013). Intravenous immunoglobulin does not reduce left ventricular remodeling in patients with myocardial dysfunction during hospitalization after acute myocardial infarction. Int. J. Cardiol. 168, 212-218. doi: 10.1016/j.ijcard.2012. 09.092

Gullestad, L., Ueland, T., Fjeld, J. G., Holt, E., Gundersen, T., Breivik, K., et al. (2005). Effect of thalidomide on cardiac remodeling in chronic heart failure: results of a double-blind, placebo-controlled study. Circulation 112, 3408-3414. doi: 10.1161/CIRCULATIONAHA.105.564971

Gullestad, L., Ueland, T., Vinge, L. E., Finsen, A., Yndestad, A., and Aukrust, P. (2012). Inflammatory cytokines in heart failure: mediators and markers. Cardiology 122, 23-35. doi: 10.1159/000338166 
Halade, G. V., Kain, V., and Serhan, C. N. (2018). Immune responsive resolvin D1 programs myocardial infarction-induced cardiorenal syndrome in heart failure. FASEB J. 32, 3717-3729. doi: 10.1096/fj.201701173RR

Hamid, T., Gu, Y., Ortines, R. V., Bhattacharya, C., Wang, G., Xuan, Y. T., et al. (2009). Divergent tumor necrosis factor receptor-related remodeling responses in heart failure: role of nuclear factor-kappaB and inflammatory activation. Circulation 119, 1386-1397. doi: 10.1161/CIRCULATIONAHA.108.802918

Hanna, A., and Frangogiannis, N. G. (2020). Inflammatory cytokines and chemokines as therapeutic targets in heart failure. Cardiovasc Drugs Ther 34, 849-863. doi: 10.1007/s10557-020-07071-0

Hare, J. M., Mangal, B., Brown, J., Fisher, C. Jr., Freudenberger, R., Colucci, W. S., et al. (2008). Impact of oxypurinol in patients with symptomatic heart failure. Results of the OPT-CHF study. J. Am. Coll. Cardiol. 51, 2301-2309. doi: 10.1016/j.jacc.2008.01.068

Harjola, V. P., Mullens, W., Banaszewski, M., Bauersachs, J., Brunner-La Rocca, H. P., Chioncel, O., et al. (2017). Organ dysfunction, injury and failure in acute heart failure: from pathophysiology to diagnosis and management. A review on behalf of the Acute Heart Failure Committee of the Heart Failure Association (HFA) of the European Society of Cardiology (ESC). Eur. J. Heart Fail. 19, 821-836. doi: 10.1002/ejhf.872

Haudek, S. B., Taffet, G. E., Schneider, M. D., and Mann, D. L. T. N. F. (2007). provokes cardiomyocyte apoptosis and cardiac remodeling through activation of multiple cell death pathways. J. Clin. Invest. 117, 2692-2701. doi: 10.1172/ JCI29134

Hazebroek, M. R., Henkens, M., Raafs, A. G., Verdonschot, J. A. J., Merken, J. J., Dennert, R. M., et al. (2021). Intravenous immunoglobulin therapy in adult patients with idiopathic chronic cardiomyopathy and cardiac parvovirus B19 persistence: a prospective, double-blind, randomized, placebo-controlled clinical trial. Eur. J. Heart Fail. 23, 302-309. doi: 10.1002/ejhf.2082

Hemmrich, K., Suschek, C. V., Lerzynski, G., and Kolb-Bachofen, V. (2003). iNOS activity is essential for endothelial stress gene expression protecting against oxidative damage. J. Appl. Physiol. (1985) 95, 1937-1946. doi: 10.1152/ japplphysiol.00419.2003

Heydari, B., Abdullah, S., Pottala, J. V., Shah, R., Abbasi, S., Mandry, D., et al. (2016). Effect of omega-3 acid ethyl esters on left ventricular remodeling after acute myocardial infarction: The OMEGA-REMODEL randomized clinical trial. Circulation 134, 378-391. doi: 10.1161/CIRCULATIONAHA.115.019949

Heymans, S., Hirsch, E., Anker, S. D., Aukrust, P., Balligand, J. L., Cohen-Tervaert, J. W., et al. (2009). Inflammation as a therapeutic target in heart failure? A scientific statement from the Translational Research Committee of the Heart Failure Association of the European Society of Cardiology. Eur. J. Heart Fail. 11, 119-129. doi: 10.1093/eurjhf/hfn043

Hochman, J. S. (2003). Cardiogenic shock complicating acute myocardial infarction: expanding the paradigm. Circulation 107, 2998-3002. doi: 10.1161/ 01.CIR.0000075927.67673.F2

Hori, M., and Yamaguchi, O. (2013). Is tumor necrosis factor-alpha friend or foe for chronic heart failure? Circ. Res. 113, 492-494. doi: 10.1161/CIRCRESAHA. 113.302024

Hsu, J. J., Ziaeian, B., and Fonarow, G. C. (2017). Heart failure with mid-range (Borderline) ejection fraction: clinical implications and future directions. JACC Heart Fail. 5, 763-771. doi: 10.1016/j.jchf.2017.06.013

Husebye, T., Eritsland, J., Arnesen, H., Bjornerheim, R., Mangschau, A., Seljeflot, I., et al. (2014). Association of interleukin 8 and myocardial recovery in patients with ST-elevation myocardial infarction complicated by acute heart failure. PLoS One 9:e112359. doi: 10.1371/journal.pone.0112359

Huynh, K., Van Tassell, B., and Chow, S. L. (2015). Predicting therapeutic response in patients with heart failure: the story of C-reactive protein. Expert Rev. Cardiovasc. Ther. 13, 153-161. doi: 10.1586/14779072.2015.1000307

Ikonomidis, I., Papadavid, E., Makavos, G., Andreadou, I., Varoudi, M., Gravanis, K., et al. (2017). Lowering interleukin-12 activity improves myocardial and vascular function compared with tumor necrosis factor-a antagonism or cyclosporine in psoriasis. Circ. Cardiovasc. Imag. 10:e006283. doi: 10.1161/ CIRCIMAGING.117.006283

TRIUMPH Investigators, Alexander, J. H., Reynolds, H. R., Stebbins, A. L., Dzavik, V., Harrington, R. A., et al. (2007). Effect of tilarginine acetate in patients with acute myocardial infarction and cardiogenic shock: the TRIUMPH randomized controlled trial. JAMA 297, 1657-1666. doi: 10.1001/jama.297.15.joc70035
Ishibashi, Y., Takahashi, N., Tokumaru, A., Karino, K., Sugamori, T., Sakane, T., et al. (2008). Activation of inducible NOS in peripheral vessels and outcomes in heart failure patients. J. Card Fail. 14, 724-731. doi: 10.1016/j.cardfail.2008.06. 450

Jabs, W. J., Theissing, E., Nitschke, M., Bechtel, J. F., Duchrow, M., Mohamed, S., et al. (2003). Local generation of C-reactive protein in diseased coronary artery venous bypass grafts and normal vascular tissue. Circulation 108, 1428-1431. doi: 10.1161/01.CIR.0000092184.43176.91

Jain, M. K., and Ridker, P. M. (2005). Anti-inflammatory effects of statins: clinical evidence and basic mechanisms. Nat. Rev. Drug Discov. 4, 977-987. doi: 10. $1038 / \mathrm{nrd} 1901$

Jan, T., Vinzenz, H., and Nienhaus, G. U. (2008). C-reactive protein and atherosclerosis: An update. Vasc. Dis. Preven. 5, 178-182. doi: 10.2174/ 1567270010805030178

Jankowska, E. A., Ponikowska, B., Majda, J., Zymlinski, R., Trzaska, M., Reczuch, K., et al. (2007). Hyperuricaemia predicts poor outcome in patients with mild to moderate chronic heart failure. Int. J. Cardiol. 115, 151-155. doi: 10.1016/j. ijcard.2005.10.033

Jobe, L. J., Melendez, G. C., Levick, S. P., Du, Y., Brower, G. L., and Janicki, J. S. (2009). TNF-alpha inhibition attenuates adverse myocardial remodeling in a rat model of volume overload. Am. J. Physiol. Heart Circ. Physiol. 297, H1462-H1468. doi: 10.1152/ajpheart.00442.2009

Jones, N. R., Pegues, M. A., McCrory, M. A., Singleton, W., Bethune, C., Baker, B. F., et al. (2012). A selective inhibitor of human C-reactive protein translation is efficacious in vitro and in C-reactive protein transgenic mice and humans. Mol. Ther. Nucleic Acids 1:e52. doi: 10.1038/mtna.2012.44

Kain, V., Liu, F., Kozlovskaya, V., Ingle, K. A., Bolisetty, S., Agarwal, A., et al. (2017). Resolution agonist 15-epi-Lipoxin A4 programs early activation of resolving phase in post-myocardial infarction healing. Sci. Rep. 7:9999. doi: 10.1038/s41598-017-10441-8

Kaluski, E., Hendler, A., Blatt, A., and Uriel, N. (2006). Nitric oxide synthase inhibitors in post-myocardial infarction cardiogenic shock-an update. Clin. Cardiol. 29, 482-488. doi: 10.1002/clc.4960291103

Kaneko, N., Kurata, M., Yamamoto, T., Morikawa, S., and Masumoto, J. (2019). The role of interleukin-1 in general pathology. Inflamm. Regen. 39:12. doi: 10.1186/s41232-019-0101-5

Kaur, K., Dhingra, S., Slezak, J., Sharma, A. K., Bajaj, A., and Singal, P. K. (2009). Biology of TNFalpha and IL-10, and their imbalance in heart failure. Heart Fail. Rev. 14, 113-123. doi: 10.1007/s10741-008-9104-z

Kelsen, S. G., Agache, I. O., Soong, W., Israel, E., Chupp, G. L., Cheung, D. S., et al. (2021). Astegolimab (anti-ST2) efficacy and safety in adults with severe asthma: A randomized clinical trial. J. Allergy Clin. Immunol. 148, 790-798. doi: 10.1016/j.jaci.2021.03.044

Kemp, C. D., and Conte, J. V. (2012). The pathophysiology of heart failure. Cardiovasc. Pathol. 21, 365-371. doi: 10.1016/j.carpath.2011.11.007

Keyes, K. T., Ye, Y., Lin, Y., Zhang, C., Perez-Polo, J. R., Gjorstrup, P., et al. (2010). Resolvin E1 protects the rat heart against reperfusion injury. Am. J. Physiol. Heart Circ. Physiol. 299, H153-H164. doi: 10.1152/ajpheart.01057.2009

Khush, K. K., Waters, D. D., Bittner, V., Deedwania, P. C., Kastelein, J. J., Lewis, S. J., et al. (2007). Effect of high-dose atorvastatin on hospitalizations for heart failure: subgroup analysis of the Treating to New Targets (TNT) study. Circulation 115, 576-583. doi: 10.1161/CIRCULATIONAHA.106.625 574

Kielar, M. L., John, R., Bennett, M., Richardson, J. A., Shelton, J. M., Chen, L., et al. (2005). Maladaptive role of IL-6 in ischemic acute renal failure. J. Am. Soc. Nephrol. 16, 3315-3325. doi: 10.1681/ASN.2003090757

Kiltz, U., Kiefer, D., Braun, J., Schiffrin, E. J., Girard-Guyonvarc'h, C., and Gabay, C. (2020). Prolonged treatment with Tadekinig alfa in adult-onset Still's disease. Ann. Rheum. Dis. 79:e10. doi: 10.1136/annrheumdis-2018-214496

Kingery, J. R., Hamid, T., Lewis, R. K., Ismahil, M. A., Bansal, S. S., Rokosh, G., et al. (2017). Leukocyte iNOS is required for inflammation and pathological remodeling in ischemic heart failure. Basic Res. Cardiol. 112:19 doi: 10.1007/ s00395-017-0609-2

Kitakaze, M., Minamino, T., Node, K., Koretsune, Y., Komamura, K., Funaya, H., et al. (1998). Elevation of plasma adenosine levels may attenuate the severity of chronic heart failure. Cardiovasc. Drugs Ther. 12, 307-309. doi: 10.1023/a: 1007726018470 
Kjekshus, J., Apetrei, E., Barrios, V., Bohm, M., Cleland, J. G., Cornel, J. H., et al. (2007). Rosuvastatin in older patients with systolic heart failure. N. Engl. J. Med. 357, 2248-2261. doi: 10.1056/NEJMoa0706201

Kleveland, O., Kunszt, G., Bratlie, M., Ueland, T., Broch, K., Holte, E., et al. (2016). Effect of a single dose of the interleukin-6 receptor antagonist tocilizumab on inflammation and troponin $\mathrm{T}$ release in patients with non-ST-elevation myocardial infarction: a double-blind, randomized, placebo-controlled phase 2 trial. Eur. Heart J. 37, 2406-2413. doi: 10.1093/eurheartj/ehw171

Kobayashi, H., Kobayashi, Y., Giles, J. T., Yoneyama, K., Nakajima, Y., and Takei, M. (2014). Tocilizumab treatment increases left ventricular ejection fraction and decreases left ventricular mass index in patients with rheumatoid arthritis without cardiac symptoms: assessed using 3.0 tesla cardiac magnetic resonance imaging. J. Rheumatol. 41, 1916-1921. doi: 10.3899/jrheum.131540

Koenig, W., Khuseyinova, N., Baumert, J., Thorand, B., Loewel, H., Chambless, L., et al. (2006). Increased concentrations of C-reactive protein and IL-6 but not IL-18 are independently associated with incident coronary events in middleaged men and women: results from the MONICA/KORA Augsburg case-cohort study, 1984-2002. Arterioscler. Thromb. Vasc. Biol. 26, 2745-2751. doi: 10.1161/ 01.ATV.0000248096.62495.73

Kohsaka, S., Menon, V., Lowe, A. M., Lange, M., Dzavik, V., Sleeper, L. A., et al. (2005). Systemic inflammatory response syndrome after acute myocardial infarction complicated by cardiogenic shock. Arch. Intern. Med. 165, 16431650. doi: 10.1001/archinte.165.14.1643

Kozhuharov, N., Goudev, A., Flores, D., Maeder, M. T., Walter, J., Shrestha, S., et al. (2019). Effect of a strategy of comprehensive vasodilation vs usual care on mortality and heart failure rehospitalization among patients with acute heart failure: The GALACTIC randomized clinical trial. JAMA 322, 2292-2302. doi: 10.1001/jama.2019.18598

Krishnamurthy, P., Rajasingh, J., Lambers, E., Qin, G., Losordo, D. W., and Kishore, R. (2009). IL-10 inhibits inflammation and attenuates left ventricular remodeling after myocardial infarction via activation of STAT3 and suppression of HuR. Circ. Res. 104, e9-e18. doi: 10.1161/CIRCRESAHA.108.188243

Krum, H., Ashton, E., Reid, C., Kalff, V., Rogers, J., Amarena, J., et al. (2007). Double-blind, randomized, placebo-controlled study of high-dose HMG CoA reductase inhibitor therapy on ventricular remodeling, pro-inflammatory cytokines and neurohormonal parameters in patients with chronic systolic heart failure. J. Card Fail. 13, 1-7. doi: 10.1016/j.cardfail.2006.09.008

Kunes, P., Holubcova, Z., Kolackova, M., and Krejsek, J. (2010). Interleukin-33, a novel member of the IL-1/IL-18 cytokine family, in cardiology and cardiac surgery. Thorac. Cardiovasc. Surg. 58, 443-449. doi: 10.1055/s-0030- 1250436

Lanier-Smith, K. L., and Currie, M. G. (1990). Effect of glucocorticoids on the binding of atrial natriuretic peptide to endothelial cells. Eur. J. Pharmacol. 178, 105-109. doi: 10.1016/0014-2999(90)94800-d

Levine, B., Kalman, J., Mayer, L., Fillit, H. M., and Packer, M. (1990). Elevated circulating levels of tumor necrosis factor in severe chronic heart failure. N. Engl. J. Med. 323, 236-241. doi: 10.1056/NEJM199007263230405

Li, K., Guo, D., Zhu, H., Hering-Smith, K. S., Hamm, L. L., Ouyang, J., et al. (2010). Interleukin-6 stimulates epithelial sodium channels in mouse cortical collecting duct cells. Am. J. Physiol. Regul. Integr. Comp. Physiol. 299, R590-R595. doi: 10.1152/ajpregu.00207.2009

Li, Y. Y., Feng, Y. Q., Kadokami, T., McTiernan, C. F., Draviam, R., Watkins, S. C., et al. (2000). Myocardial extracellular matrix remodeling in transgenic mice overexpressing tumor necrosis factor alpha can be modulated by anti-tumor necrosis factor alpha therapy. Proc. Natl. Acad. Sci. U S A 97, 12746-12751. doi: 10.1073/pnas.97.23.12746

Liu, C., Chen, H., Zhou, C., Ji, Z., Liu, G., Gao, Y., et al. (2006). Potent potentiating diuretic effects of prednisone in congestive heart failure. J. Cardiovasc. Pharmacol. 48, 173-176. doi: 10.1097/01.fjc.0000245242.57088.5b

Liu, C., Liu, G., Zhou, C., Ji, Z., Zhen, Y., and Liu, K. (2007). Potent diuretic effects of prednisone in heart failure patients with refractory diuretic resistance. Can. J. Cardiol. 23, 865-868. doi: 10.1016/s0828-282x(07)70840-1

Liu, C., Liu, K., and Cope-Adhf Study Group. (2014). Cardiac outcome prevention effectiveness of glucocorticoids in acute decompensated heart failure: COPEADHF study. J. Cardiovasc. Pharmacol. 63, 333-338. doi: 10.1097/FJC. 0000000000000048

Lourenco, P., Paulo Araujo, J., Paulo, C., Mascarenhas, J., Frioes, F., Azevedo, A., et al. (2010). Higher C-reactive protein predicts worse prognosis in acute heart failure only in noninfected patients. Clin. Cardiol. 33, 708-714. doi: 10.1002/clc. 20812

Maeda, K., Tsutamoto, T., Wada, A., Mabuchi, N., Hayashi, M., Tsutsui, T., et al. (2000). High levels of plasma brain natriuretic peptide and interleukin-6 after optimized treatment for heart failure are independent risk factors for morbidity and mortality in patients with congestive heart failure. J. Am. Coll. Cardiol. 36, 1587-1593. doi: 10.1016/s0735-1097(00)00912-8

Mallat, Z., Corbaz, A., Scoazec, A., Besnard, S., Leseche, G., Chvatchko, Y., et al. (2001). Expression of interleukin-18 in human atherosclerotic plaques and relation to plaque instability. Circulation 104, 1598-1603. doi: 10.1161/hc3901. 096721

Mallat, Z., Heymes, C., Corbaz, A., Logeart, D., Alouani, S., Cohen-Solal, A., et al. (2004). Evidence for altered interleukin 18 (IL)-18 pathway in human heart failure. FASEB J. 18, 1752-1754. doi: 10.1096/fj.04-2426fje

Mann, D. L. (2015). Innate immunity and the failing heart: the cytokine hypothesis revisited. Circ. Res. 116, 1254-1268. doi: 10.1161/CIRCRESAHA.116.302317

Mann, D. L., McMurray, J. J., Packer, M., Swedberg, K., Borer, J. S., Colucci, W. S., et al. (2004). Targeted anticytokine therapy in patients with chronic heart failure: results of the Randomized Etanercept Worldwide Evaluation (RENEWAL). Circulation 109, 1594-1602. doi: 10.1161/01.CIR.0000124490. 27666.B2

Manzano-Fernandez, S., Mueller, T., Pascual-Figal, D., Truong, Q. A., and Januzzi, J. L. (2011). Usefulness of soluble concentrations of interleukin family member ST2 as predictor of mortality in patients with acutely decompensated heart failure relative to left ventricular ejection fraction. Am. J. Cardiol. 107, 259-267. doi: 10.1016/j.amjcard.2010.09.011

Massari, F., Mastropasqua, F., Iacoviello, M., Nuzzolese, V., Torres, D., and Parrinello, G. (2012). The glucocorticoid in acute decompensated heart failure: Dr Jekyll or Mr Hyde? Am. J. Emerg. Med. 30:517. doi: 10.1016/j.ajem.2011.01. 023

Mattecka, S., Brunner, P., Hahnel, B., Kunze, R., Vogt, B., and Sheriff, A. (2019). PentraSorb C-reactive protein: characterization of the selective c-reactive protein adsorber resin. Ther. Apher. Dial. 23, 474-481. doi: 10.1111/1744-9987. 12796

Mattila, P., Majuri, M. L., Mattila, P. S., and Renkonen, R. (1992). TNF alphainduced expression of endothelial adhesion molecules, ICAM-1 and VCAM-1, is linked to protein kinase C activation. Scand. J. Immunol. 36, 159-165. doi: 10.1111/j.1365-3083.1992.tb03087.x

McCarthy, C. P., and Januzzi, J. L. Jr. (2018). Soluble ST2 in heart failure. Heart Fail. Clin. 14, 41-48. doi: 10.1016/j.hfc.2017.08.005

McKie, E. A., Reid, J. L., Mistry, P. C., DeWall, S. L., Abberley, L., Ambery, P. D., et al. (2016). A Study to investigate the efficacy and safety of an anti-interleukin18 monoclonal antibody in the treatment of type 2 diabetes mellitus. PLoS One 11:e0150018. doi: 10.1371/journal.pone.0150018

Mebazaa, A., Tolppanen, H., Mueller, C., Lassus, J., DiSomma, S., Baksyte, G., et al. (2016). Acute heart failure and cardiogenic shock: a multidisciplinary practical guidance. Intensive Care Med. 42, 147-163. doi: 10.1007/s00134-015-4041-5

Mentz, R. J., and O'Connor, C. M. (2016). Pathophysiology and clinical evaluation of acute heart failure. Nat. Rev. Cardiol. 13, 28-35. doi: 10.1038/nrcardio.2015. 134

Michelucci, A., Ricciardi, G., Sofi, F., Gori, A. M., Pirolo, F., Pieragnoli, P., et al. (2007). Relation of inflammatory status to major adverse cardiac events and reverse remodeling in patients undergoing cardiac resynchronization therapy. J. Card Fail. 13, 207-210. doi: 10.1016/j.cardfail.2006.11.013

Mihara, M., Hashizume, M., Yoshida, H., Suzuki, M., and Shiina, M. (2012). IL6/IL-6 receptor system and its role in physiological and pathological conditions. Clin. Sci. (Lond.) 122, 143-159. doi: 10.1042/CS20110340

Moe, G. W., Marin-Garcia, J., Konig, A., Goldenthal, M., Lu, X., and Feng, Q. (2004). In vivo TNF-alpha inhibition ameliorates cardiac mitochondrial dysfunction, oxidative stress, and apoptosis in experimental heart failure. Am. J. Physiol. Heart Circ. Phys. 287, H1813-H1820. doi: 10.1152/ajpheart.00036.2004

Moertl, D., Hammer, A., Steiner, S., Hutuleac, R., Vonbank, K., and Berger, R. (2011). Dose-dependent effects of omega-3-polyunsaturated fatty acids on systolic left ventricular function, endothelial function, and markers of inflammation in chronic heart failure of nonischemic origin: a double-blind, placebo-controlled, 3-arm study. Am. Heart J. 161:915. doi: 10.1016/j.ahj.2011. 02.011 
Montesinos, M. C., Yap, J. S., Desai, A., Posadas, I., McCrary, C. T., and Cronstein, B. N. (2000). Reversal of the antiinflammatory effects of methotrexate by the nonselective adenosine receptor antagonists theophylline and caffeine: evidence that the antiinflammatory effects of methotrexate are mediated via multiple adenosine receptors in rat adjuvant arthritis. Arthritis Rheum. 43, 656-663. doi: 10.1002/1529-0131(200003)43:3<656::AID-ANR23<3.0.CO;2-H

Moreira, D. M., Vieira, J. L., and Gottschall, C. A. (2009). The effects of METhotrexate therapy on the physical capacity of patients with ISchemic heart failure: a randomized double-blind, placebo-controlled trial (METIS trial). J. Card Fail. 15, 828-834. doi: 10.1016/j.cardfail.2009.06.439

Murphy, S. P., Kakkar, R., McCarthy, C. P., and Januzzi, J. L. Jr. (2020). Inflammation in heart failure: JACC state-of-the-art review. J. Am. Coll. Cardiol. 75, 1324-1340. doi: 10.1016/j.jacc.2020.01.014

Ndrepepa, G. (2019). Myeloperoxidase - A bridge linking inflammation and oxidative stress with cardiovascular disease. Clin. Chim. Acta 493, 36-51. doi: 10.1016/j.cca.2019.02.022

Nelander, K., Lagerstrom-Fermer, M., Amilon, C., Michaelsson, E., Heijer, M., Kjaer, M., et al. (2021). Early clinical experience with AZD4831, a novel myeloperoxidase inhibitor, developed for patients with heart failure with preserved ejection fraction. Clin. Transl. Sci. 14, 812-819. doi: 10.1111/cts. 12859

Nessler, J., Nessler, B., Golebiowska-Wiatrak, R., Palka, I., Gackowski, A., Kitlinski, M., et al. (2013). Serum biomarkers and clinical outcomes in heart failure patients treated de novo with carvedilol. Cardiol. J. 20, 144-151. doi: 10.5603/ CJ.2013.0027

Ng, L. L., Pathik, B., Loke, I. W., Squire, I. B., and Davies, J. E. (2006). Myeloperoxidase and C-reactive protein augment the specificity of B-type natriuretic peptide in community screening for systolic heart failure. Am. Heart J. 152, 94-101. doi: 10.1016/j.ahj.2005.09.020

Ng, T. M., and Toews, M. L. (2016). Impaired norepinephrine regulation of monocyte inflammatory cytokine balance in heart failure. World J. Cardiol. 8, 584-589. doi: 10.4330/wjc.v8.i10.584

Niazi, M., Galehdar, N., Jamshidi, M., Mohammadi, R., and Moayyedkazemi, A. (2020). A review of the role of statins in heart failure treatment. Curr. Clin. Pharmacol. 15, 30-37. doi: 10.2174/1574884714666190802125627

Nimmerjahn, F., and Ravetch, J. V. (2008). Anti-inflammatory actions of intravenous immunoglobulin. Annu. Rev. Immunol. 26, 513-533. doi: 10.1146/ annurev.immunol.26.021607.090232

Nymo, S. H., Hulthe, J., Ueland, T., McMurray, J., Wikstrand, J., Askevold, E. T., et al. (2014). Inflammatory cytokines in chronic heart failure: interleukin- 8 is associated with adverse outcome. Results from CORONA. Eur. J. Heart Fail. 16, 68-75. doi: 10.1093/eurjhf/hft125

O’Brien, L. C., Mezzaroma, E., Van Tassell, B. W., Marchetti, C., Carbone, S., Abbate, A., et al. (2014). Interleukin-18 as a therapeutic target in acute myocardial infarction and heart failure. Mol. Med. 20, 221-229. doi: 10.2119/ molmed.2014.00034

Pacher, P., Beckman, J. S., and Liaudet, L. (2007). Nitric oxide and peroxynitrite in health and disease. Physiol. Rev. 87, 315-424. doi: 10.1152/physrev.00029.2006

Paulus, W. J., and Tschope, C. (2013). A novel paradigm for heart failure with preserved ejection fraction: comorbidities drive myocardial dysfunction and remodeling through coronary microvascular endothelial inflammation. J. Am. Coll. Cardiol. 62, 263-271. doi: 10.1016/j.jacc.2013.02.092

Paulus, W. J., and Zile, M. R. (2021). From systemic inflammation to myocardial fibrosis: The heart failure with preserved ejection fraction paradigm revisited. Circ. Res. 128, 1451-1467. doi: 10.1161/CIRCRESAHA.121.318159

Pepys, M. B., Hirschfield, G. M., Tennent, G. A., Gallimore, J. R., Kahan, M. C., Bellotti, V., et al. (2006). Targeting C-reactive protein for the treatment of cardiovascular disease. Nature 440:7088. doi: 10.1038/nature04672

Perez, A. L., Grodin, J. L., Chaikijurajai, T., Wu, Y., Hernandez, A. F., Butler, J., et al. (2021). Interleukin-6 and outcomes in acute heart failure: An ASCEND-HF substudy. J. Card Fail. 27, 670-676. doi: 10.1016/j.cardfail.2021.01.006

Pitt, B., Pfeffer, M. A., Assmann, S. F., Boineau, R., Anand, I. S., Claggett, B., et al. (2014). Spironolactone for heart failure with preserved ejection fraction. N. Engl. J. Med. 370, 1383-1392. doi: 10.1056/NEJMoa1313731

Pollheimer, J., Bodin, J., Sundnes, O., Edelmann, R. J., Skanland, S. S., Sponheim, J., et al. (2013). Interleukin-33 drives a proinflammatory endothelial activation that selectively targets nonquiescent cells. Arterioscler. Thromb. Vasc. Biol. 33, e47-e55. doi: 10.1161/ATVBAHA.112.253427
Ponikowski, P., Voors, A. A., Anker, S. D., Bueno, H., Cleland, J. G., Coats, A. J., et al. (2016). 2016 ESC Guidelines for the diagnosis and treatment of acute and chronic heart failure: The Task Force for the diagnosis and treatment of acute and chronic heart failure of the European Society of Cardiology (ESC). Developed with the special contribution of the Heart Failure Association (HFA) of the ESC. Eur. J. Heart Fail. 18, 891-975. doi: 10.1002/ejhf.592

Prondzinsky, R., Unverzagt, S., Lemm, H., Wegener, N. A., Schlitt, A., Heinroth, K. M., et al. (2012). Interleukin-6, $-7,-8$ and -10 predict outcome in acute myocardial infarction complicated by cardiogenic shock. Clin. Res. Cardiol. 101, 375-384. doi: 10.1007/s00392-011-0403-3

Pugliese, N. R., Fabiani, I., Conte, L., Nesti, L., Masi, S., Natali, A., et al. (2020). Persistent congestion, renal dysfunction and inflammatory cytokines in acute heart failure: a prognosis study. J. Cardiovasc. Med. (Hagerstown) 21, 494-502. doi: 10.2459/JCM.0000000000000974

Putko, B. N., Wang, Z., Lo, J., Anderson, T., Becher, H., Dyck, J. R., et al. (2014). Circulating levels of tumor necrosis factor-alpha receptor 2 are increased in heart failure with preserved ejection fraction relative to heart failure with reduced ejection fraction: evidence for a divergence in pathophysiology. PLoS One 9:e99495. doi: 10.1371/journal.pone.0099495

Ramani, G. V., Uber, P. A., and Mehra, M. R. (2010). Chronic heart failure: contemporary diagnosis and management. Mayo Clin. Proc. 85, 180-195. doi: 10.4065/mcp.2009.0494

Rathi, S. S., Xu, Y. J., and Dhalla, N. S. (2002). Mechanism of cardioprotective action of TNF-alpha in the isolated rat heart. Exp. Clin. Cardiol. 7, 146-150.

Real, J., Cowles, E., Wierzbicki, A. S., and Guideline, C. (2018). Chronic heart failure in adults: summary of updated NICE guidance. BMJ 362:k3646. doi: 10.1136/bmj.k3646

Redfield, M. M., Anstrom, K. J., Levine, J. A., Koepp, G. A., Borlaug, B. A., Chen, H. H., et al. (2015). Isosorbide mononitrate in heart failure with preserved ejection fraction. N. Engl. J. Med. 373, 2314-2324. doi: 10.1056/ NEJMoa1510774

Reichlin, T., Socrates, T., Egli, P., Potocki, M., Breidthardt, T., Arenja, N., et al. (2010). Use of myeloperoxidase for risk stratification in acute heart failure. Clin. Chem. 56, 944-951. doi: 10.1373/clinchem.2009.142257

Reina-Couto, M., Silva-Pereira, C., Bessa, J., Oliveira-Santos, M., Serrão, P., Afonso, J., et al. (2019b). Inflammation and resolution of inflammation in human acute heart failure. Int. Care Med. Exp. 7, 588-589. doi: 10.1186/s40635-019-0265-y1

Reina-Couto, M., Bessa, J., Oliveira-Santos, M., Serrão, P., Afonso, J., RonconAlbuquerque, R., et al. (2019a). Resolvins in human acute heart failure. Eur. J. Clin. Invest. 49, 204-205. doi: 10.1111/eci.13109

Reina-Couto, M., Carvalho, J., Valente, M. J., Vale, L., Afonso, J., Carvalho, F., et al. (2014). Impaired resolution of inflammation in human chronic heart failure. Eur. J. Clin. Invest. 44, 527-538. doi: 10.1111/eci.12265

Reina-Couto, M., Vale, L., Carvalho, J., Bettencourt, P., Albino-Teixeira, A., and Sousa, T. (2016). Resolving inflammation in heart failure: novel protective lipid mediators. Curr. Drug Targets 17, 1206-1223. doi: 10.2174/ 1389450117666160101121135

Reina-Couto, M., Silva-Pereira, C., Terra, P., Quelhas-Santos, J., Pinho, D., Martins, S., et al. (2020). Proinflammatory cytokines and endothelial cell activation in human acute heart failure versus septic shock. Int. Care Med. Exp. 8:73. doi: 10.1186/s40635-020-00354-8

Ridker, P. M., Buring, J. E., Cook, N. R., and Rifai, N. (2003). C-reactive protein, the metabolic syndrome, and risk of incident cardiovascular events: an 8year follow-up of 14719 initially healthy American women. Circulation 107, 391-397. doi: 10.1161/01.cir.0000055014.62083.05

Ridker, P. M., Devalaraja, M., Baeres, F. M. M., Engelmann, M. D. M., Hovingh, G. K., Ivkovic, M., et al. (2021). IL-6 inhibition with ziltivekimab in patients at high atherosclerotic risk (RESCUE): a double-blind, randomised, placebocontrolled, phase 2 trial. Lancet 397, 2060-2069.

Ridker, P. M., Everett, B. M., Thuren, T., MacFadyen, J. G., Chang, W. H., Ballantyne, C., et al. (2017). Antiinflammatory therapy with canakinumab for atherosclerotic disease. N. Engl. J. Med. 377, 1119-1131. doi: 10.1056/ NEJMoa1707914

Ridker, P. M., and Group, J. S. (2003). Rosuvastatin in the primary prevention of cardiovascular disease among patients with low levels of low-density lipoprotein cholesterol and elevated high-sensitivity C-reactive protein: rationale and design of the JUPITER trial. Circulation 108, 2292-2297. doi: 10.1161/01.CIR.0000100688.17280.E6 
Ridker, P. M., MacFadyen, J. G., Everett, B. M., Libby, P., Thuren, T., Glynn, R. J., et al. (2018). Relationship of C-reactive protein reduction to cardiovascular event reduction following treatment with canakinumab: a secondary analysis from the CANTOS randomised controlled trial. Lancet 391, 319-328. doi: 10. 1016/S0140-6736(17)32814-3

Ries, W., Heigl, F., Garlichs, C., Sheriff, A., and Torzewski, J. (2019). Selective C-reactive protein-apheresis in patients. Ther. Apher. Dial. 23, 570-574. doi: 10.1111/1744-9987.12804

Ries, W., Sheriff, A., Heigl, F., Zimmermann, O., Garlichs, C. D., and Torzewski, J. (2018). "First in Man": case report of selective C-reactive protein apheresis in a patient with acute ST segment elevation myocardial infarction. Case Rep. Cardiol. 2018:4767105. doi: 10.1155/2018/4767105

Rongen, G. A., Floras, J. S., Lenders, J. W., Thien, T., and Smits, P. (1997). Cardiovascular pharmacology of purines. Clin. Sci. (Lond.) 92, 13-24. doi: $10.1042 / \operatorname{cs} 0920013$

Saini, H. K., Xu, Y. J., Zhang, M., Liu, P. P., Kirshenbaum, L. A., and Dhalla, N. S. (2005). Role of tumour necrosis factor-alpha and other cytokines in ischemiareperfusion-induced injury in the heart. Exp. Clin. Cardiol. 10, 213-222.

Sanada, S., Hakuno, D., Higgins, L. J., Schreiter, E. R., McKenzie, A. N., and Lee, R. T. (2007). IL-33 and ST2 comprise a critical biomechanically induced and cardioprotective signaling system. J. Clin. Invest. 117, 1538-1549. doi: 10.1172/ JCI30634

Sanchez, I., Santana, S., Escobar, C., Santiago, J. L., Gonzalez, A., Ribas, N., et al. (2014). Clinical implications of different biomarkers in elderly patients with heart failure. Biomark Med. 8, 535-541. doi: 10.2217/bmm.14.24

Sanders, D. B., Larson, D. F., Hunter, K., Gorman, M., and Yang, B. (2001). Comparison of tumor necrosis factor-alpha effect on the expression of iNOS in macrophage and cardiac myocytes. Perfusion 16, 67-74. doi: 10.1177/ 026765910101600110

Scirica, B. M., Morrow, D. A., Cannon, C. P., Ray, K. K., Sabatine, M. S., Jarolim, P., et al. (2006). Intensive statin therapy and the risk of hospitalization for heart failure after an acute coronary syndrome in the PROVE IT-TIMI 22 study. J. Am. Coll. Cardiol. 47, 2326-2331. doi: 10.1016/j.jacc.2006.03.034

Segiet, O. A., Piecuch, A., Mielanczyk, L., Michalski, M., and NowalanyKozielska, E. (2019a). Role of interleukins in heart failure with reduced ejection fraction. Anatol. J. Cardiol. 22, 287-299. doi: 10.14744/AnatolJCardiol.2019.32 748

Segiet, O. A., Romuk, E., Nowalany-Kozielska, E., Wojciechowska, C., Piecuch, A., and Wojnicz, R. (2019b). The concentration of interleukin-33 in heart failure with reduced ejection fraction. Anatol. J. Cardiol. 21, 305-313. doi: 10.14744/ AnatolJCardiol.2019.64614

Seta, Y., Kanda, T., Tanaka, T., Arai, M., Sekiguchi, K., Yokoyama, T., et al. (2000). Interleukin 18 in acute myocardial infarction. Heart 84:668. doi: 10.1136/heart. 84.6.668

Seta, Y., Shan, K., Bozkurt, B., Oral, H., and Mann, D. L. (1996). Basic mechanisms in heart failure: the cytokine hypothesis. J Card Fail 2, 243-249. doi: 10.1016/ s1071-9164(96)80047-9

Sethuramalingam, S., Maiti, R., Hota, D., and Srinivasan, A. (2021). Effect of colchicine in reducing inflammatory biomarkers and cardiovascular risk in coronary artery disease: A meta-analysis of clinical trials. Am. J. Ther. [Epub ahead of print]. doi: 10.1097/MJT.0000000000001409

Sheriff, A., Kayser, S., Brunner, P., and Vogt, B. (2021). C-reactive protein triggers cell death in ischemic cells. Front. Immunol. 12:630430. doi: 10.3389/fimmu. 2021.630430

Shpektor, A. (2010). Cardiogenic shock: the role of inflammation. Acute Card Care 12, 115-118. doi: 10.3109/17482941.2010.523705

Sivasubramanian, N., Coker, M. L., Kurrelmeyer, K. M., MacLellan, W. R., DeMayo, F. J., Spinale, F. G., et al. (2001). Left ventricular remodeling in transgenic mice with cardiac restricted overexpression of tumor necrosis factor. Circulation 104, 826-831. doi: 10.1161/hc3401.093154

Sliwa, K., Woodiwiss, A., Candy, G., Badenhorst, D., Libhaber, C., Norton, G., et al. (2002). Effects of pentoxifylline on cytokine profiles and left ventricular performance in patients with decompensated congestive heart failure secondary to idiopathic dilated cardiomyopathy. Am. J. Cardiol. 90, 1118-1122. doi: 10. 1016/s0002-9149(02)02779-0

Sliwa, K., Woodiwiss, A., Kone, V. N., Candy, G., Badenhorst, D., Norton, G., et al. (2004). Therapy of ischemic cardiomyopathy with the immunomodulating agent pentoxifylline: results of a randomized study. Circulation 109, 750-755. doi: 10.1161/01.CIR.0000112568.48837.60

Solomon, S. D., Vaduganathan, M., Claggett, B. L., Packer, M., Zile, M., Swedberg, K., et al. (2020). Sacubitril/Valsartan across the spectrum of ejection fraction in heart failure. Circulation 141, 352-361. doi: 10.1161/CIRCULATIONAHA.119. 044586

Song, Y., Li, F., Xu, Y., Liu, Y., Wang, Y., Han, X., et al. (2020). Prognostic value of sST2 in patients with heart failure with reduced, mid-range and preserved ejection fraction. Int. J. Cardiol. 304, 95-100. doi: 10.1016/j.ijcard.2020.01.039

Soskic, S. S., Dobutovic, B. D., Sudar, E. M., Obradovic, M. M., Nikolic, D. M., Djordjevic, J. D., et al. (2011). Regulation of Inducible Nitric Oxide Synthase (iNOS) and its potential role in insulin resistance, diabetes and heart failure. Open Cardiovasc. Med. J. 5, 153-163. doi: 10.2174/1874192401105010153

Sousa, T., Reina-Couto, M., and Gomes, P. (2019). "Role of Oxidative Stress in the Pathophysiology of Arterial Hypertension and Heart Failure," in Oxidative Stress in Heart Diseases, eds S. Chakraborti, N. S. Dhalla, N. K. Ganguly, and M. Dikshit (Singapore: Springer), 509-537.

Speranza, L., Franceschelli, S., Riccioni, G., Di Nicola, M., Ruggeri, B., Gallina, S., et al. (2012). BNP and iNOS in decompensated chronic heart failure: a linear correlation. Front Biosci (Elite Ed). 4, 1255-1262. doi: 10.2741/456

Spodick, D. H. (2003). Acute cardiac tamponade. N. Engl. J. Med. 349, 684-690. doi: 10.1056/NEJMra022643

Srivastava, P. K., Hsu, J. J., Ziaeian, B., and Fonarow, G. C. (2020). Heart failure with mid-range ejection fraction. Curr. Heart Fail. Rep. 17, 1-8. doi: 10.1007/ s11897-019-00451-0

Stull, L. B., Leppo, M. K., Szweda, L., Gao, W. D., and Marban, E. (2004). Chronic treatment with allopurinol boosts survival and cardiac contractility in murine postischemic cardiomyopathy. Circ. Res. 95, 1005-1011. doi: 10.1161/01.RES. 0000148635.73331.c5

Suematsu, N., Tsutsui, H., Wen, J., Kang, D., Ikeuchi, M., Ide, T., et al. (2003). Oxidative stress mediates tumor necrosis factor-alpha-induced mitochondrial DNA damage and dysfunction in cardiac myocytes. Circulation 107, 1418-1423. doi: 10.1161/01.cir.0000055318.09997.1f

Sun, K. J., Liu, L. L., Hu, J. H., Chen, Y. Y., and Xu, D. Y. (2021). Methotrexate can prevent cardiovascular events in patients with rheumatoid arthritis: An updated meta-analysis. Medicine (Baltimore) 100:e24579. doi: 10.1097/MD. 0000000000024579

Sun, M., Chen, M., Dawood, F., Zurawska, U., Li, J. Y., Parker, T., et al. (2007). Tumor necrosis factor-alpha mediates cardiac remodeling and ventricular dysfunction after pressure overload state. Circulation 115, 1398-1407. doi: 10. 1161/CIRCULATIONAHA.106.643585

Szalai, A. J., McCrory, M. A., Xing, D., Hage, F. G., Miller, A., Oparil, S., et al. (2014). Inhibiting C-reactive protein for the treatment of cardiovascular disease: promising evidence from rodent models. Mediators Inflamm. 2014:353614. doi: 10.1155/2014/353614

Szekely, Y., and Arbel, Y. (2018). A review of interleukin-1 in heart disease: where do we stand today? Cardiol. Ther. 7, 25-44. doi: 10.1007/s40119-018-0104-3

Tamariz, L., and Hare, J. M. (2015). Xanthine oxidase inhibitors in heart failure: where do we go from here? Circulation 131, 1741-1744. doi: 10.1161/ CIRCULATIONAHA.115.016379

Tamariz, L., Harzand, A., Palacio, A., Verma, S., Jones, J., and Hare, J. (2011). Uric acid as a predictor of all-cause mortality in heart failure: a meta-analysis. Congest. Heart Fail. 17, 25-30. doi: 10.1111/j.1751-7133.2011.00200.x

Tang, L., Wang, H., and Ziolo, M. T. (2014). Targeting NOS as a therapeutic approach for heart failure. Pharmacol. Ther. 142, 306-315. doi: 10.1016/j. pharmthera.2013.12.013

Tang, W. H., Brennan, M. L., Philip, K., Tong, W., Mann, S., Van Lente, F., et al. (2006). Plasma myeloperoxidase levels in patients with chronic heart failure. Am. J. Cardiol. 98, 796-799. doi: 10.1016/j.amjcard.2006.04.018

Tang, W. H., Tong, W., Troughton, R. W., Martin, M. G., Shrestha, K., Borowski, A., et al. (2007). Prognostic value and echocardiographic determinants of plasma myeloperoxidase levels in chronic heart failure. J. Am. Coll. Cardiol. 49, 2364-2370. doi: 10.1016/j.jacc.2007.02.053

Tavazzi, L., Maggioni, A. P., Marchioli, R., Barlera, S., Franzosi, M. G., Latini, R., et al. (2008b). Effect of rosuvastatin in patients with chronic heart failure (the GISSI-HF trial): a randomised, double-blind, placebo-controlled trial. Lancet 372, 1231-1239. doi: 10.1016/S0140-6736(08)61240-4 
Tavazzi, L., Maggioni, A. P., Marchioli, R., Barlera, S., Franzosi, M. G., Latini, R., et al. (2008a). Effect of n-3 polyunsaturated fatty acids in patients with chronic heart failure (the GISSI-HF trial): a randomised, double-blind, placebocontrolled trial. Lancet 372, 1223-1230. doi: 10.1016/S0140-6736(08)61 239-8

Taylor, A. L., Ziesche, S., Yancy, C., Carson, P., D’Agostino, R. Jr., Ferdinand, K., et al. (2004). Combination of isosorbide dinitrate and hydralazine in blacks with heart failure. N. Engl. J. Med. 351, 2049-2057. doi: 10.1056/NEJMoa042934

Tentolouris, C., Tousoulis, D., Antoniades, C., Bosinakou, E., Kotsopoulou, M., Trikas, A., et al. (2004). Endothelial function and proinflammatory cytokines in patients with ischemic heart disease and dilated cardiomyopathy. Int. J. Cardiol. 94, 301-305. doi: 10.1016/j.ijcard.2003.08.002

Thiele, J. R., Zeller, J., Bannasch, H., Stark, G. B., Peter, K., and Eisenhardt, S. U. (2015). Targeting C-Reactive protein in inflammatory disease by preventing conformational changes. Mediators Inflamm. 2015:372432. doi: 10.1155/2015/ 372432

Tomasoni, D., Adamo, M., Lombardi, C. M., and Metra, M. (2019). Highlights in heart failure. ESC Heart Fail. 6, 1105-1127. doi: 10.1002/ehf2.12555

Tourki, B., and Halade, G. V. (2021). Heart failure syndrome with preserved ejection fraction is a metabolic cluster of non-resolving inflammation in obesity. Front. Cardiovasc. Med. 8:695952. doi: 10.3389/fcvm.2021.695952

Tourki, B., Kain, V., Shaikh, S. R., Leroy, X., Serhan, C. N., and Halade, G. V. (2020). Deficit of resolution receptor magnifies inflammatory leukocyte directed cardiorenal and endothelial dysfunction with signs of cardiomyopathy of obesity. FASEB J. 34, 10560-10573. doi: 10.1096/fj.2020004 95RR

Tschope, C., Ammirati, E., Bozkurt, B., Caforio, A. L. P., Cooper, L. T., Felix, S. B., et al. (2021). Myocarditis and inflammatory cardiomyopathy: current evidence and future directions. Nat. Rev. Cardiol. 18, 169-193. doi: 10.1038/s41569-02000435- $\mathrm{x}$

Tsutamoto, T., Hisanaga, T., Wada, A., Maeda, K., Ohnishi, M., Fukai, D., et al. (1998). Interleukin-6 spillover in the peripheral circulation increases with the severity of heart failure, and the high plasma level of interleukin- 6 is an important prognostic predictor in patients with congestive heart failure. J. Am. Coll. Cardiol. 31, 391-398. doi: 10.1016/s0735-1097(97)00494-4

Urschel, K., and Cicha, I. (2015). TNF- $\alpha$ in the cardiovascular system: from physiology to therapy. Int. J. Interferon Cytokine Media. Res. 7, 9-25. doi: 10.2147/IJICMR.S64894

van Diepen, S., Katz, J. N., Albert, N. M., Henry, T. D., Jacobs, A. K., Kapur, N. K., et al. (2017). Contemporary management of cardiogenic shock: A scientific statement from the american heart association. Circulation 136:e232-e268. doi: 10.1161/CIR.0000000000000525

Van Linthout, S., and Tschope, C. (2017). Inflammation - cause or consequence of heart failure or both? Curr. Heart Fail. Rep. 14, 251-265. doi: 10.1007/s11897017-0337-9

Van Linthout, S., and Tschope, C. (2019). The quest for antiinflammatory and immunomodulatory strategies in heart failure. Clin. Pharmacol. Ther. 106, 1198-1208. doi: 10.1002/cpt.1637

Van Tassell, B. W., Abouzaki, N. A., Oddi Erdle, C., Carbone, S., Trankle, C. R., Melchior, R. D., et al. (2016). Interleukin-1 blockade in acute decompensated heart failure: A randomized, double-blinded, placebo-controlled pilot study. J. Cardiovasc. Pharmacol. 67, 544-551. doi: 10.1097/FJC.0000000000000378

Van Tassell, B. W., Arena, R., Biondi-Zoccai, G., Canada, J. M., Oddi, C., Abouzaki, N. A., et al. (2014). Effects of interleukin-1 blockade with anakinra on aerobic exercise capacity in patients with heart failure and preserved ejection fraction (from the D-HART pilot study). Am. J. Cardiol. 113, 321-327. doi: 10.1016/j. amjcard.2013.08.047

Van Tassell, B. W., Arena, R. A., Toldo, S., Mezzaroma, E., Azam, T., Seropian, I. M., et al. (2012). Enhanced interleukin-1 activity contributes to exercise intolerance in patients with systolic heart failure. PLoS One 7:e33438. doi: 10.1371/journal. pone.0033438

Van Tassell, B. W., Canada, J., Carbone, S., Trankle, C., Buckley, L., Oddi Erdle, C., et al. (2017). Interleukin-1 blockade in recently decompensated systolic heart failure: results from REDHART (Recently Decompensated Heart Failure Anakinra Response Trial). Circ. Heart Fail. 10:e004373. doi: 10.1161/ CIRCHEARTFAILURE.117.004373

Van Tassell, B. W., Trankle, C. R., Canada, J. M., Carbone, S., Buckley, L., Kadariya, D., et al. (2018). IL-1 blockade in patients with heart failure with preserved ejection fraction. Circ. Heart Fail. 11:e005036. doi: 10.1161/ CIRCHEARTFAILURE.118.005036

van Veldhuisen, D. J., Cohen-Solal, A., Bohm, M., Anker, S. D., Babalis, D., Roughton, M., et al. (2009). Beta-blockade with nebivolol in elderly heart failure patients with impaired and preserved left ventricular ejection fraction: Data From SENIORS (Study of Effects of Nebivolol Intervention on Outcomes and Rehospitalization in Seniors With Heart Failure). J. Am. Coll. Cardiol. 53, 2150-2158. doi: 10.1016/j.jacc.2009.02.046

Vasan, R. S., Sullivan, L. M., Roubenoff, R., Dinarello, C. A., Harris, T., Benjamin, E. J., et al. (2003). Inflammatory markers and risk of heart failure in elderly subjects without prior myocardial infarction: the Framingham Heart Study. Circulation 107, 1486-1491. doi: 10.1161/01.cir.0000057810.48709.f6

Vasilyev, N., Williams, T., Brennan, M. L., Unzek, S., Zhou, X., Heinecke, J. W., et al. (2005). Myeloperoxidase-generated oxidants modulate left ventricular remodeling but not infarct size after myocardial infarction. Circulation 112, 2812-2820. doi: 10.1161/CIRCULATIONAHA.105.542340

Vejlstrup, N. G., Bouloumie, A., Boesgaard, S., Andersen, C. B., Nielsen-Kudsk, J. E., Mortensen, S. A., et al. (1998). Inducible nitric oxide synthase (iNOS) in the human heart: expression and localization in congestive heart failure. J. Mol. Cell. Cardiol. 30, 1215-1223. doi: 10.1006/jmcc.1998.0686

Verma, S. K., Krishnamurthy, P., Barefield, D., Singh, N., Gupta, R., Lambers, E., et al. (2012). Interleukin-10 treatment attenuates pressure overload-induced hypertrophic remodeling and improves heart function via signal transducers and activators of transcription 3-dependent inhibition of nuclear factorkappaB. Circulation 126, 418-429. doi: 10.1161/CIRCULATIONAHA.112. 112185

Villegas, S., Villarreal, F. J., and Dillmann, W. H. (2000). Leukemia inhibitory factor and interleukin-6 downregulate sarcoplasmic reticulum Ca2+ ATPase (SERCA2) in cardiac myocytes. Basic Res. Cardiol. 95, 47-54. doi: 10.1007/ s003950050007

Virzi, G. M., Breglia, A., Brocca, A., de Cal, M., Bolin, C., Vescovo, G., et al. (2018). Levels of proinflammatory cytokines, oxidative stress, and tissue damage markers in patients with acute heart failure with and without cardiorenal syndrome type 1. Cardiorenal. Med. 8, 321-331. doi: 10.1159/000492602

Wang, M., Markel, T. A., and Meldrum, D. R. (2008). Interleukin 18 in the heart. Shock 30, 3-10. doi: 10.1097/SHK.0b013e318160f215

Webb, C. A., and Barry, A. R. (2020). Colchicine for secondary cardiovascular prevention: A systematic review. Pharmacotherapy 40, 575-583. doi: 10.1002/ phar.2401

White, M., Ducharme, A., Ibrahim, R., Whittom, L., Lavoie, J., Guertin, M. C., et al. (2006). Increased systemic inflammation and oxidative stress in patients with worsening congestive heart failure: improvement after short-term inotropic support. Clin. Sci. (Lond) 110, 483-489. doi: 10.1042/CS20050317

Wlodek, E., Kirkpatrick, R. B., Andrews, S., Noble, R., Schroyer, R., Scott, J., et al. (2021). A pilot study evaluating GSK1070806 inhibition of interleukin-18 in renal transplant delayed graft function. PLoS One 16:e0247972. doi: 10.1371/ journal.pone.0247972

Xiang, N., Liao, H., Zhai, Z., and Gong, J. (2021). Expression and significance of inflammatory reactions mediated by the IL-33/ST2 signaling pathway in the serum of heart failure patients. Am. J. Transl. Res. 13, 8247-8252.

Yang, Y., Lv, J., Jiang, S., Ma, Z., Wang, D., Hu, W., et al. (2016). The emerging role of Toll-like receptor 4 in myocardial inflammation. Cell. Death Dis. 7:e2234. doi: $10.1038 /$ cddis.2016.140

Yano, M., Nishino, M., Ukita, K., Kawamura, A., Nakamura, H., Matsuhiro, Y., et al. (2021). High density lipoprotein cholesterol / C reactive protein ratio in heart failure with preserved ejection fraction. ESC Heart Fail. 8, 2791-2801. doi: 10.1002/ehf2.13350

Yasojima, K., Schwab, C., McGeer, E. G., and McGeer, P. L. (2001). Generation of C-reactive protein and complement components in atherosclerotic plaques. Am. J. Pathol. 158, 1039-1051. doi: 10.1016/S0002-9440(10)64051-5

Yndestad, A., Damas, J. K., Oie, E., Ueland, T., Gullestad, L., and Aukrust, P. (2006). Systemic inflammation in heart failure-the whys and wherefores. Heart Fail. Rev. 11, 83-92. doi: 10.1007/s10741-006-9196-2

Yokoe, I., Kobayashi, H., Kobayashi, Y., Giles, J. T., Yoneyama, K., Kitamura, N., et al. (2018). Impact of tocilizumab on $\mathrm{N}$-terminal pro-brain natriuretic peptide levels in patients with active rheumatoid arthritis without cardiac symptoms. Scand. J. Rheumatol. 47, 364-370. doi: 10.1080/03009742.2017.1418424 
Yokoyama, T., Vaca, L., Rossen, R. D., Durante, W., Hazarika, P., and Mann, D. L. (1993). Cellular basis for the negative inotropic effects of tumor necrosis factor-alpha in the adult mammalian heart. J. Clin. Invest. 92, 2303-2312.

Yusuf, S., Pfeffer, M. A., Swedberg, K., Granger, C. B., Held, P., McMurray, J. J., et al. (2003). Effects of candesartan in patients with chronic heart failure and preserved left-ventricular ejection fraction: the CHARM-Preserved Trial. Lancet 362, 777-781. doi: 10.1016/S0140-6736(03)14285-7

Zell, R., Geck, P., Werdan, K., and Boekstegers, P. (1997). TNF-alpha and IL-1 alpha inhibit both pyruvate dehydrogenase activity and mitochondrial function in cardiomyocytes: evidence for primary impairment of mitochondrial function. Mol. Cell. Biochem. 177, 61-67. doi: 10.1023/a:1006896832582

Zhang, H., Liu, C., Ji, Z., Liu, G., Zhao, Q., Ao, Y. G., et al. (2008). Prednisone adding to usual care treatment for refractory decompensated congestive heart failure. Int. Heart J. 49, 587-595. doi: 10.1536/ihj.49.587

Zhang, H. F., Xie, S. L., Chen, Y. X., Mai, J. T., Wang, J. F., Zhu, W. L., et al. (2012). Altered serum levels of IL-33 in patients with advanced systolic chronic heart failure: correlation with oxidative stress. J. Transl. Med. 10:120. doi: 10.1186/ 1479-5876-10-120

Zhang, M., Xu, Y. J., Mengi, S. A., Arneja, A. S., and Dhalla, N. S. (2004). Therapeutic potentials of pentoxifylline for treatment of cardiovascular diseases. Exp. Clin. Cardiol. 9, 103-111.

Zhang, P., Xu, X., Hu, X., van Deel, Zhu, G., and Chen, Y. (2007). Inducible nitric oxide synthase deficiency protects the heart from systolic overload-induced ventricular hypertrophy and congestive heart failure. Circ. Res. 100, 1089-1098. doi: 10.1161/01.RES.0000264081.78659.45

Zhang, W., Wang, W., Yu, H., Zhang, Y., Dai, Y., Ning, C., et al. (2012). Interleukin 6 underlies angiotensin II-induced hypertension and chronic renal damage.
Hypertension 59, 136-144. doi: 10.1161/HYPERTENSIONAHA.111.173 328

Zimmermann, O., Bienek-Ziolkowski, M., Wolf, B., Vetter, M., Baur, R., Mailander, V., et al. (2009). Myocardial inflammation and non-ischaemic heart failure: is there a role for C-reactive protein? Basic Res. Cardiol. 104, 591-599. doi: 10.1007/s00395-009-0026-2

Zimmet, J. M., and Hare, J. M. (2006). Nitroso-redox interactions in the cardiovascular system. Circulation 114, 1531-1544. doi: 10.1161/ CIRCULATIONAHA.105.605519

Conflict of Interest: The authors declare that the research was conducted in the absence of any commercial or financial relationships that could be construed as a potential conflict of interest.

Publisher's Note: All claims expressed in this article are solely those of the authors and do not necessarily represent those of their affiliated organizations, or those of the publisher, the editors and the reviewers. Any product that may be evaluated in this article, or claim that may be made by its manufacturer, is not guaranteed or endorsed by the publisher.

Copyright (C) 2021 Reina-Couto, Pereira-Terra, Quelhas-Santos, Silva-Pereira Albino-Teixeira and Sousa. This is an open-access article distributed under the terms of the Creative Commons Attribution License (CC BY). The use, distribution or reproduction in other forums is permitted, provided the original author(s) and the copyright owner(s) are credited and that the original publication in this journal is cited, in accordance with accepted academic practice. No use, distribution or reproduction is permitted which does not comply with these terms. 